\title{
Carbon uptake and biogeochemical change in the Southern Ocean, south of Tasmania
}

\author{
Paula Conde Pardo ${ }^{1}$, Bronte Tilbrook ${ }^{1,2}$, Clothilde Langlais ${ }^{2}$, Thomas William Trull ${ }^{1,2}$, and Stephen Rich Rintoul ${ }^{1,2}$ \\ ${ }^{1}$ Antarctic Climate and Ecosystem Cooperative Research Centre, University of Tasmania, Hobart, Australia \\ ${ }^{2}$ Climate Science Centre, CSIRO Oceans and Atmosphere, Hobart, Australia \\ Correspondence to: Paula C. Pardo (paula.condepardo@csiro.au)
}

Received: 29 May 2017 - Discussion started: 7 June 2017

Revised: 27 September 2017 - Accepted: 2 October 2017 - Published: 21 November 2017

\begin{abstract}
Biogeochemical change in the water masses of the Southern Ocean, south of Tasmania, was assessed for the 16-year period between 1995 and 2011 using data from four summer repeats of the WOCE-JGOFS-CLIVARGO-SHIP (Key et al., 2015; Olsen et al., 2016) SR03 hydrographic section (at $\sim 140^{\circ} \mathrm{E}$ ). Changes in temperature, salinity, oxygen, and nutrients were used to disentangle the effect of solubility, biology, circulation and anthropogenic carbon $\left(\mathrm{C}_{\mathrm{ANT}}\right)$ uptake on the variability of dissolved inorganic carbon (DIC) for eight water mass layers defined by neutral surfaces $\left(\gamma^{n}\right)$. C $C_{\text {ANT }}$ was estimated using an improved back-calculation method. Warming $\left(\sim 0.0352 \pm 0.0170^{\circ} \mathrm{C} \mathrm{yr}^{-1}\right)$ of Subtropical Central Water (STCW) and Antarctic Surface Water (AASW) layers decreased their gas solubility, and accordingly DIC concentrations increased less rapidly than expected from equilibration with rising atmospheric $\mathrm{CO}_{2}\left(\sim 0.86 \pm 0.16 \mu \mathrm{mol} \mathrm{kg}^{-1} \mathrm{yr}^{-1}\right.$ versus $\left.\sim 1 \pm 0.12 \mu \mathrm{mol} \mathrm{kg}^{-1} \mathrm{yr}^{-1}\right)$. An increase in apparent oxygen utilisation (AOU) occurred in these layers due to either remineralisation of organic matter or intensification of upwelling. The range of estimates for the increases in $\mathrm{C}_{\mathrm{ANT}}$ were $0.71 \pm 0.08$ to $0.93 \pm 0.08 \mu \mathrm{mol} \mathrm{kg} \mathrm{kg}^{-1} \mathrm{yr}^{-1}$ for STCW and $0.35 \pm 0.14$ to $0.65 \pm 0.21 \mu \mathrm{mol} \mathrm{kg}^{-1} \mathrm{yr}^{-1}$ for AASW, with the lower values in each water mass obtained by assigning all the AOU change to remineralisation. DIC increases in the Sub-Antarctic Mode Water (SAMW, $1.10 \pm 0.14 \mu \mathrm{mol} \mathrm{kg}^{-1} \mathrm{yr}^{-1}$ ) and Antarctic Intermediate Water (AAIW, $0.40 \pm 0.15 \mu \mathrm{mol} \mathrm{kg}^{-1} \mathrm{yr}^{-1}$ ) layers were similar to the calculated $\mathrm{C}_{\mathrm{ANT}}$ trends. For SAMW, the $\mathrm{C}_{\mathrm{ANT}}$ increase tracked rising atmospheric $\mathrm{CO}_{2}$. As a consequence of the general DIC increase, decreases in total $\mathrm{pH}\left(\mathrm{pH}_{\mathrm{T}}\right)$ and aragonite saturation $\left(\Omega_{\mathrm{Ar}}\right)$
\end{abstract}

were found in most water masses, with the upper ocean and the SAMW layer presenting the largest trends for $\mathrm{pH}_{\mathrm{T}}$ decrease $\left(\sim-0.0031 \pm 0.0004 \mathrm{yr}^{-1}\right)$. DIC increases in deep and bottom layers $\left(\sim 0.24 \pm 0.04 \mu \mathrm{mol} \mathrm{kg}^{-1} \mathrm{yr}^{-1}\right)$ resulted from the advection of old deep waters to resupply increased upwelling, as corroborated by increasing silicate $\left(\sim 0.21 \pm 0.07 \mu \mathrm{mol} \mathrm{kg} \mathrm{kg}^{-1} \mathrm{yr}^{-1}\right)$, which also reached the upper layers near the Antarctic Divergence $\left(\sim 0.36 \pm 0.06 \mu \mathrm{mol} \mathrm{kg}^{-1} \mathrm{yr}^{-1}\right)$ and was accompanied by an increase in salinity. The observed changes in DIC over the 16-year span caused a shoaling $(\sim 340 \mathrm{~m})$ of the aragonite saturation depth (ASD, $\Omega_{\mathrm{Ar}}=1$ ) within Upper Circumpolar Deep Water that followed the upwelling path of this layer. From all our results, we conclude a scenario of increased transport of deep waters into the section and enhanced upwelling at high latitudes for the period between 1995 and 2011 linked to strong westerly winds. Although enhanced upwelling lowered the capacity of the AASW layer to uptake atmospheric $\mathrm{CO}_{2}$, it did not limit that of the newly forming SAMW and AAIW, which exhibited $\mathrm{C}_{\mathrm{ANT}}$ storage rates $\left(\sim 0.41 \pm 0.20 \mathrm{~mol} \mathrm{~m}^{-2} \mathrm{yr}^{-1}\right)$ twice that of the upper layers.

\section{Introduction}

The Southern Ocean is a key region in terms of climate change and climate variability, influencing the Meridional Overturning Circulation (MOC) and therefore modulating the global circulation and oceanic biogeochemical cycles (Sarmiento et al., 1998, 2004; Orr et al., 2005). Deep waters, formed in the North Atlantic, spread south and enter the Southern Ocean, where they mix with deep layers of the 
Antarctic Circumpolar Current (ACC) and ultimately upwell between the Southern ACC Front and the Polar Front. The upwelled waters are eventually transformed into bottom, intermediate and mode waters, which are exported from the Southern Ocean to ventilate the thermocline and bottom layers of the major ocean basins. Some of the Southern Ocean waters subducted into the ocean interior return to the North Atlantic to balance the southward flux of North Atlantic Deep Water (Speer et al., 2000; Lumpkin and Speer, 2007; Iudicone et al., 2008).

Within the eastward flow of the ACC, major water exchange between the three ocean basins takes place. The circumpolar path of the ACC consists of various narrow jets associated with sharp fronts that separate waters with different characteristics (Orsi et al., 1995; Belkin and Gordon, 1996). These jets can reach deep layers and often meander, intensify, merge and split, conditioned by the topography of the ocean floor, the stratification of the ACC, and atmospheric variability (Moore et al., 1999; Sokolov and Rintoul, 2002, 2009; Peña-Molino et al., 2014). Movements in the jets enhance cross-stream transports and mesoscale activity that can result in local changes in water mass properties and this may complicate the computation of long-term changes in water mass properties (Rintoul and Bullister, 1999; Sallée et al., 2008; Peña-Molino et al., 2014).

Water mass formation and ventilation transport heat, salt, and dissolved gases from the atmosphere to the ocean interior and other basins (Sarmiento et al., 2004), with the Southern Ocean contributing $\sim 40 \%$ to the anthropogenic $\mathrm{CO}_{2}$ $\left(\mathrm{C}_{\mathrm{ANT}}\right)$ inventory of the ocean (Sabine et al., 2004; Gruber et al., 2009; Khatiwala et al., 2009). Circulation and biological processes drive the redistribution of dissolved inorganic carbon (DIC) that ultimately affects the capacity of the waters to uptake more $\mathrm{CO}_{2}$. The uptake of $\mathrm{CO}_{2}$ by the Southern Ocean presents strong spatiotemporal variability (Lenton et al., 2013), and this can lead to conflicting results for observational studies, models and atmospheric inversions, depending on the methodology used (Verdy et al., 2007; Lenton et al., 2012; Fay et al., 2014). Quantifying long-term changes in the carbon system is difficult due to the scarcity of data (Lenton et al., 2012; Kouketsu and Murata, 2014; Fay et al., 2014) and the influence of biological processes. Notably, long-term trends in $\mathrm{C}_{\mathrm{ANT}}$ concentration are difficult to estimate due to its small signal $(\sim 3 \%)$ with respect to that of DIC in the ocean.

Once $\mathrm{CO}_{2}$ dissolves in the ocean (DIC) it begins the process of ocean acidification, i.e. decreases the $\mathrm{pH}$ and the saturation state of calcium carbonate $\left(\mathrm{CaCO}_{3}\right)$ minerals such as calcite and aragonite (Feely et al., 2004; Bates et al., 2014), with potential to disrupt ecosystems and biological processes (Doney et al., 2009).

Numerous studies have documented warming and freshening of deep and bottom layers of the Southern Ocean in recent decades (see reviews by Jacobs, 2006 and van Wijk and Rintoul, 2014). The abyssal waters of the Australian-

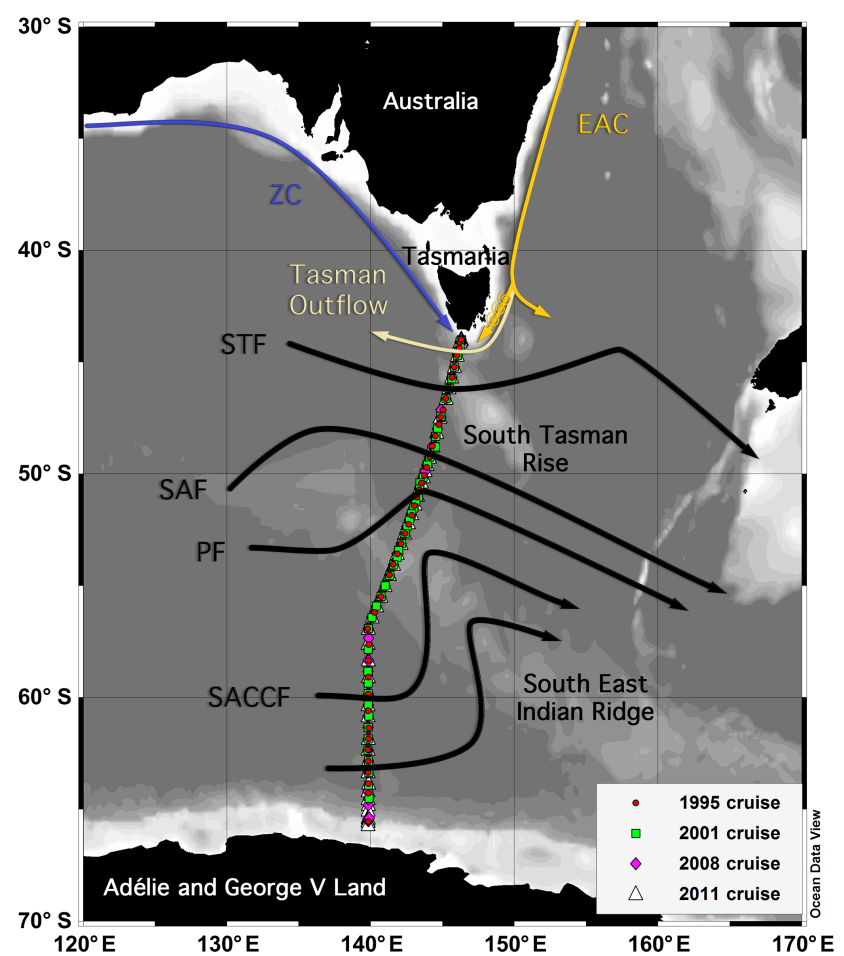

Figure 1. Transects of the four summer repeats of the G0-SHIP hydrodynamic line SR03 in the Southern Ocean south of Tasmania for the period 1995-2011 and the main hydrography features of the region. $\mathrm{ZC}=$ Zeehan Current. EAC $=$ East Australian Current. Black arrows indicate the flow of the Antarctic Circumpolar Current $(\mathrm{ACC})$, with $\mathrm{STF}=$ Subtropical Front; $\mathrm{SAF}=$ Sub-Antarctic Front, $\mathrm{PF}=$ Polar Front and SACCF $=$ Southern ACC Front.

Antarctic Basin (A-AB) show the greatest freshening in the last 40 years (van Wijk and Rintoul, 2014). This freshening was accompanied by a warming of the deep-bottom layers, leading to a contraction in bottom waters by more than half their volume in the basin (Purkey and Johnson, 2012; van Wijk and Rintoul, 2014). Subsurface to intermediate layers have also warmed and freshened south of Australia (Bindoff and Church, 1992; Wong et al., 1999; Aoki et al., 2005). The solubility of gases and their distribution in the ocean depend on the dynamics and properties of water masses, and the thermohaline changes that have occurred south of Tasmania (Fig. 1) have implications in the carbon system of the region.

A reduction of the carbon sink of the Southern Ocean was observed between the 1980s and the early 2000s (Le Quéré et al., 2007; Lovenduski et al., 2008), with more recent studies suggesting a recovery and even intensification of the $\mathrm{CO}_{2}$ uptake by 2011-2012 (Zickfeld et al., 2008; Fay et al., 2014; Landschützer et al., 2015). DeVries et al. (2017), used a global inverse model to postulate that changes in circulation are responsible for most of the variability in the oceanic $\mathrm{CO}_{2}$ uptake, with the weakening of the upper-ocean circulation being responsible for the increase in oceanic carbon uptake 
Table 1. Repeats of the GO-SHIP SR03 line on board the Aurora Australis from 1995 to 2011 with the expocode from GLODAPv2 database.

\begin{tabular}{lll}
\hline EXPOCODE & Dates (dd/mm/yyyy) & REF. \\
\hline 09AR19941213 & 20/12/1994-1/02/1995 & 1995 \\
09AR20011029 & 29/10/2001-11/12/2001 & 2001 \\
09AR20080322 & $23 / 03 / 2008-15 / 04 / 2008$ & 2008 \\
09AR20110124 & $4 / 01 / 2011-31 / 01 / 2011$ & 2011 \\
\hline
\end{tabular}

over the past decade. Ocean acidification has been observed in the whole Southern Ocean (Lauvset et al., 2015) and locally in the Atlantic and Pacific sectors (Williams et al., 2015; Hauri et al., 2015). South of Tasmania, McNeil et al. (2001) reported an increase in $\mathrm{C}_{\mathrm{ANT}}$ uptake between 1968 and 1996 for the region $45-50^{\circ} \mathrm{S}$. These authors reported, for the first time, $\mathrm{C}_{\mathrm{ANT}}$ accumulation in the $\mathrm{AABW}$ and highlighted the importance of the formation of bottom and mode waters as a mechanism for transporting $\mathrm{C}_{\mathrm{ANT}}$ to the ocean. In terms of ocean acidification, we are not aware of any study about trends in ocean acidification in the water masses south of Australia.

Considering the lack of observational estimates for recent biogeochemical changes in the $\mathrm{A}-\mathrm{AB}$ as well as the large changes in $\mathrm{CO}_{2}$ uptake and storage suggested by recent atmospheric and surface observations in the Southern Ocean (e.g. Fay et al., 2014; Landschützer et al., 2015) there is a need to provide a full ocean depth observational perspective on how the ocean is changing. The aim of this paper is to provide the first estimates of biogeochemical change in the water masses south of Tasmania, for the period 19952011, disentangling the effects that solubility, circulation, biology and $\mathrm{C}_{\mathrm{ANT}}$ uptake have on the variability of DIC. We use data from four summer repeats of the (Key et al., 2015; Olsen et al., 2016) WOCE-JGOFS-CLIVAR-GO-SHIP hydrographic section SR03 (Fig. 1; Table 1), one of the most revisited sections in the Southern Ocean. Trends in oxygen $\left(\mathrm{O}_{2}\right)$, nutrients, and the carbon system parameters (i.e. DIC, total alkalinity (TA), anthropogenic carbon $\left(\mathrm{C}_{\mathrm{ANT}}\right)$, total $\mathrm{pH}$ $\left(\mathrm{pH}_{\mathrm{T}}\right)$ and percentage aragonite saturation $\left.\left(\Omega_{\mathrm{Ar}}\right)\right)$ were estimated for the period 1995-2011, when both DIC and TA measurements are available. $\mathrm{C}_{\mathrm{ANT}}$ estimates were obtained with a back-calculation method (Pardo et al., 2014). The changes were evaluated in the different water mass layers of the section defined by neutral surfaces $\left(\gamma^{\mathrm{n}}\right.$, McDougall et al., 1987).

\section{Hydrography of the region}

The dynamical structure of the region south of Tasmania (Fig. 1) is characterized by a number of fronts that separate the major water masses of the region (Sokolov and Rintoul, 2002, 2007, 2009). At the northern end of the section, the presence of the weak Subtropical Front (STF, Fig. 1) separates warm, salty subtropical surface waters from cooler and fresher sub-Antarctic surface waters (Deacon, 1937). The northern end of the section is a complex mixing zone where waters transported down the east coast of Tasmania in a series of mesoscale eddies from the East Australian Current (EAC, Fig. 1) mix into the Subantarctic Zone, and also meet Zeehan Current (ZC, Fig. 1) waters transported down the west coast of Tasmania (Boland and Church, 1981; Baines et al., 1983; Speich et al., 2002; Davis, 2005; Ridgway et al., 2007; Sloyan et al., 2016). The EAC transported south of Tasmania forms a zonal jet towards the south-east Indian Ocean, known as the Tasman Outflow, that reaches the bottom of the Tasman slope and that is maintained all year round (Rintoul and Bullister, 1999; Ridgway et al., 2007). The encounter between these currents presents high variability at the northern end of the section (Fig. 1).

Farther south (Fig. 1), the Sub-Antarctic Front (SAF) and the Polar Front $(\mathrm{PF})$ are regions of maximum transport in the ACC (Rintoul and Bullister, 1999; Sokolov and Rintoul, 2002). North of the SAF, deep winter convection generates Sub-Antarctic Mode Water (SAMW), a relatively uniform water mass that occupies subsurface layers down to $\sim 600 \mathrm{~m}$ deep (McCartney, 1977; Rintoul and Bullister, 1999). SAMW constitutes the main part of the upper limb of the MOC, ventilating the thermocline of all the ocean basins (e.g. Speer et al., 2000; Sloyan and Rintoul, 2001). The SAF coincides with the deepening of the salinity minimum at intermediate depths (Whitworth III and Nowlin Jr., 1987), which is the signature of the Antarctic Intermediate Water (AAIW). The AAIW underlies the SAMW and also ventilates the global thermocline layers of the ocean. It is mainly formed in the south-east Pacific and it is continuously transformed on its way to the region south of Tasmania (Hanawa and Talley, 2001). South of the SAF, colder and fresher Antarctic Surface Water (AASW) covers the surface ocean. AASW originates from progressive warming of Winter Water (WW, Mosby, 1934), which can be perceived even in summer as a remnant layer of cold water at the base of the AASW (Rintoul et al., 1997).

The Southern ACC Front (SACCF, Fig. 1) is a deep front located south of the PF (Orsi et al., 1995) and can coincide with the southern boundary of the ACC, which is represented by the southern limit of the oxygen minimum (Orsi et al., 1995). The oxygen minimum is related to the advection of Upper Circumpolar Deep Water (UCDW) that originates in the Indian and Pacific Oceans (Callahan, 1972), from where it spreads south, mixes with deep layers of the ACC and ultimately upwells near the Antarctic continent as part of the lower cell of the MOC. Lower Circumpolar Deep Water (LCDW) is below UCDW and is identified by a salinity maximum and contributes to upwelling around Antarctica. The precursor of the LCDW is North Atlantic Deep Water (NADW), which originates in the Labrador and Nordic seas of the North Atlantic polar region (Dickson and Brown, 
1984) that flows southward to enter the ACC as part of the MOC (Callahan, 1972; Orsi et al., 1995; Johnson, 2008).

At the southern end of the section, the Antarctic Slope Front forms the boundary between cold and fresh shelf water and relatively warm and salty waters offshore (Jacobs, 1991). Polynyas along the Adélie and George V Land coast (Fig. 1) contribute to the formation of Adélie Land Bottom Water (ALBW), which is a mixture of High-Salinity Shelf Water (HSSW) resulting from brine rejection during ice formation and ultra-modified LCDW (Foster and Carmack, 1976; Rintoul, 1998; Marsland et al., 2004). ALBW constitutes $25 \%$ of the total volume of water $<0{ }^{\circ} \mathrm{C}$ in the ocean (Rintoul, 1998). The bottom waters near the southern end of the section also contain a component of Ross Sea Bottom Water (RSBW) that originates to the east and is deflected westwards towards the A-AB as it is transported down the continental slope. The RSBW is modified when it arrives at the location of the SR03 section by mixing with deep layers of the ACC and recently formed ALBW (Gordon and Tchernia, 1972; Rintoul, 1998). The ALBW and the modified RSBW together ventilate the abyssal layers of the A-AB before spreading north to ventilate the Indian and Pacific basins (Mantyla and Reid, 1995; Fukamachi et al., 2010).

\section{Data and method}

\subsection{Data}

The SR03 hydrographic section between Tasmania and Antarctica (Fig. 1) was occupied between 1991 and 2011. Measurements of total alkalinity (TA) were only available from the beginning of 1995, and our evaluation of biogeochemical changes is limited to four summer sections occupied for the period 1995-2011 (Table 1). A winter cruise in 1996 was not considered in this study in order to minimise seasonal biases.

Water column salinity, temperature, pressure and dissolved oxygen $\left(\mathrm{O}_{2}\right)$ were collected from the conductivitytemperature-depth (CTD) device with an accuracy of \pm 0.002 for salinity and temperature, $\pm 0.015 \%$ of full-scale range for pressure and $\pm 1 \%$ for $\mathrm{O}_{2}$, according to WOCE standards (Joyce and Corry, 1994). Samples from the Niskin bottles were analysed for DIC by coulometry and TA by open cell potentiometric titration (Dickson et al., 2007). Certified reference material provided by A. Dickson, Scripps Institution of Oceanography, were used as reference standards for DIC and TA. The precisions of DIC and TA measurements improved slightly on more recent sections, and for all sections were better than $\pm 2 \mu \mathrm{mol} \mathrm{kg}{ }^{-1}$, for both variables, based on analysis of duplicate samples and certified reference material. Samples for dissolved $\mathrm{O}_{2}$ were measured using modified Winkler titrations (Hood et al 2010), with an estimated accuracy and precision of $\pm 0.3 \%$ for the sections. For the 1995 cruise, sensor-based $\mathrm{O}_{2}$ was used instead of sampled $\mathrm{O}_{2}$ because of the poor quality of many of the Winkler measurements.

Other variables of the dissolved $\mathrm{CO}_{2}$ system were calculated from the DIC and TA measurements. We calculate $\mathrm{pH}_{\mathrm{T}}$ and $\Omega_{\mathrm{Ar}}$ (from measured DIC and TA) using the CO2sys program from Lewis and Wallace (1998) adapted to MATLAB by van Heuven et al. (2011). We use the constants for the carbonic acid from Mehrbach et al. (1973) refit by Dickson and Millero (1987), the $\mathrm{CO}_{2}$ solubility equation from Weiss (1974), dissociation constants for sulfate from Dickson (1990) and borate constant from Uppstrom (1974). Aragonite saturation states $\left(\Omega_{\mathrm{Ar}}\right)$ are calculated because it is a less stable form of $\mathrm{CaCO}_{3}$ than calcite and is the predominant biogenic form of $\mathrm{CaCO}_{3}$ precipitated by calcifying organisms.

Data presented here were interpolated to a regular grid, and the water mass layers were defined as layers between neutral surfaces $\left(\gamma^{\mathrm{n}}\right)$ determined using potential temperature and salinity and published literature values (Table 2, Sect. 2). The first $50 \mathrm{~m}$ of the water column were eliminated in order to reduce the short-timescale variability in surface properties. The use of $\gamma^{n}$ to identify the water mass layers reduces the variability due to isopycnal heave caused for example by eddies and internal waves (McDougall et al., 1987; Bindoff and McDougall, 1994; Jackett and McDougall, 1997). The upper ocean layers south of the SAF were divided into the

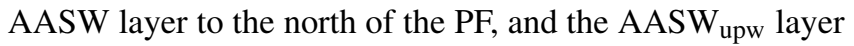
that is composed of surface waters south of the PF (Fig. 1). ADLBW and RSBW were included in the AABW layer (Table 2). The ACC fronts along the SR03 section (Table 3) were defined as a function of hydrographic variables following Sokolov and Rintoul (2002).

\subsection{Estimates of anthropogenic carbon $\left(\mathrm{C}_{\mathrm{ANT}}\right)$}

$\mathrm{C}_{\mathrm{ANT}}$ was estimated using a back-calculation method (Chen and Millero, 1979; Gruber, 1998) combined with an optimum multi-parameter (OMP) analysis (Tomczak, 1981), described by Pardo et al. (2014). This technique has the advantage of considering water mass mixing and the temporal variability of the air-sea $\mathrm{CO}_{2}$ disequilibrium. The accuracy of the method is $\pm 6 \mu \mathrm{mol} \mathrm{kg}^{-1}$ (Pardo et al., 2014). Back-calculation methods assume the ocean is at steady state for dynamical and biological processes and estimate $\mathrm{C}_{\mathrm{ANT}}$ $\left(\mathrm{C}_{\mathrm{ANT}}\right.$ BC $)$ as an excess of DIC in the ocean resulting from the increase in atmospheric $\mathrm{CO}_{2}$ due to anthropogenic emissions as follows:

$C_{\mathrm{ANT} \_\mathrm{BC}}=\mathrm{DIC}-\mathrm{DIC}^{\mathrm{BIO}}-\mathrm{DIC}^{\pi}$,

where $\mathrm{DIC}^{\mathrm{BIO}}$ is the biological contribution to DIC, and $\mathrm{DIC}^{\pi}$ is the preformed concentration of DIC in pre-industrial times. 
Table 2. Definition of the water mass layers between neutral surfaces $\left(\gamma^{\mathrm{n}}\right)$ and references used to accordingly decide the limits of the layers. We also consider limits in salinity, depth and position of the ACC fronts (see Table 3 ) to differentiate better some of the layers.

\begin{tabular}{llll}
\hline Layer & Definition & Complete name & Reference \\
\hline STCW & $\Upsilon^{\mathrm{n}}<26.85 \& \mathrm{~S} \geq 34.3$ & Subtropical Central Water & Rintoul (1998) \\
AASW & $\Upsilon^{\mathrm{n}}<27.7 \& \mathrm{~S}<34.3$ & Antarctic Surface Water & Rintoul (1998); \\
& & Williams et al. (2015) \\
AASW & $\Upsilon^{\mathrm{n}} \geq 27.7 \&$ depth $\leq 300 \mathrm{~m}$ & Antarctic Surface Water & - \\
SAMW & $26.85 \leq \Upsilon^{\mathrm{n}}<27.2 \& \mathrm{~S} \geq 34.3$ & Sub-Antarctic Mode Water & Rintoul (1998); \\
& & & Rintoul and Bullister (1999) \\
AAIW & $27.2 \leq \Upsilon^{\mathrm{n}}<27.7 \& \mathrm{~S} \geq 34.3$ & Antarctic Intermediate Water & Rintoul and Bullister (1999) \\
UCDW & $27.7 \leq \Upsilon^{\mathrm{n}}<28.18 \&$ depth $>300 \mathrm{~m}$ & Upper Circumpolar Deep water & Williams et al. (2015) \\
LCDW & $28.18 \leq \Upsilon^{\mathrm{n}}<28.25$ & Lower Circumpolar Deep Water & Lacarra et al. (2011); \\
& & Williams et al. (2015) & \\
AABW & $\Upsilon^{\mathrm{n}} \geq 28.25$ & Antarctic Bottom Water & Rintould and Bullister (1999); \\
& & & Williams et al. (2015) \\
\hline
\end{tabular}

The term DIC ${ }^{\mathrm{BIO}}$ is calculated (Chen et al., 1982; Ikegami and Kanamori, 1983) by the following:

$\mathrm{DIC}^{\mathrm{BIO}}=\frac{\mathrm{AOU}}{R_{\mathrm{C}}}+\frac{1}{2}\left[\mathrm{TA}-\mathrm{TA}^{0}+\mathrm{AOU} \cdot\left(\frac{1}{R_{\mathrm{N}}}+\frac{1}{R_{\mathrm{P}}}\right)\right]$,

where $R_{\mathrm{C}}, R_{\mathrm{N}}$ and $R_{\mathrm{P}}$ are the stoichiometric ratios of carbon, nitrate and phosphate respectively, referred to $\mathrm{O}_{2}$ consumption by respiration-remineralisation processes that are considered constant (1.45, 9 and 125, respectively, Broecker, 1974; Anderson and Sarmiento, 1994; Martiny et al., 2013).

The term $\frac{\mathrm{AOU}}{R_{\mathrm{C}}}$ represents the remineralisation of organic matter, with the apparent oxygen utilisation (AOU) defined as $\mathrm{AOU}=\mathrm{O}_{\mathrm{SAT}}-\mathrm{O}_{2}$, i.e. the difference between the saturation of oxygen $\left(\mathrm{O}_{\mathrm{SAT}}\right)$ at the potential temperature $(\theta)$ and salinity of the measured $\mathrm{O}_{2}$, and the measured $\mathrm{O}_{2}$. The term $\frac{1}{2}\left[\mathrm{TA}-\mathrm{TA}^{0}+\mathrm{AOU} \cdot\left(\frac{1}{R_{\mathrm{N}}}+\frac{1}{R_{\mathrm{P}}}\right)\right]$ represents the dissolution or precipitation of $\mathrm{CaCO}_{3}$, with $\mathrm{TA}^{0}$, the preformed alkalinity, obtained in the water formation sites using regional parameterisations as functions of salinity, $\theta$ and phosphate (Pardo et al., 2011; Vázquez-Rodríguez et al., 2012; Supplement Sect. S3, Table S3).

The preformed pre-industrial term, $\mathrm{DIC}^{\pi}$, is the total concentration of carbon dioxide in seawater saturated with respect to the pre-industrial $p \mathrm{CO}_{2}\left(\mathrm{DIC}_{\mathrm{SAT}}^{\pi}\right)$ and corrected for an air-sea $\mathrm{CO}_{2}$ disequilibrium $\left(\mathrm{CDIS}^{\pi}\right)$ term:

$\mathrm{DIC}^{\pi}=\mathrm{DIC}_{\mathrm{SAT}}^{\pi}+\mathrm{CDIS}^{\pi}$.

$\mathrm{CDIS}^{\pi}$ is time dependent:

$\mathrm{CDIS}^{\pi}=\mathrm{CDIS}-\delta \mathrm{CDIS}$,

where CDIS is the current disequilibrium between the ocean and the atmosphere $p \mathrm{CO}_{2}$, and $\delta \mathrm{CDIS}$ is the change in the disequilibrium from pre-industrial to current times. CDIS was obtained by similar parameterisations to those used for $\mathrm{TA}^{0}$, combined with monthly mean values of atmospheric
$\mathrm{CO}_{2}$ values from the NOAA network (Dlugokencky et al., 2016) (see Sect. S3 and Table S3). The $\delta$ CDIS values were obtained from results of the $1 / 10^{\circ}$ resolution carbon model OFAM3-WOMBAT (Sect. S1).

Interior values of preformed variables $\left(\mathrm{TA}^{0}\right.$ and $\left.\mathrm{DIC}_{\mathrm{SAT}}^{\pi}\right)$ and CDIS $^{\pi}$ were obtained using an OMP analysis to mix endmembers as described in Sects. S2 and S3, using the endmembers in Table S1 in the Supplement. The OMP analysis is based on the assumption that a property measured in a certain point is the result of linear mixing between endmembers, known as source water types (SWTs). A system of equations is created for each measurement point and is solved to obtain the fractions of the different SWTs (Sect. S2). The application of the OMP analysis requires good regional hydrodynamic knowledge as the results are strongly dependent on the definition of the SWTs (Tomczak, 1981). We used 11 SWTs to characterise the biogeochemical properties of the waters in the SR03 section and the SWT properties were assumed to be constant with time (Table S1, Fig. S1).

Small negative values of $\mathrm{C}_{\mathrm{ANT} \_\mathrm{BC}}$ can occur due to an overestimation of the $\mathrm{CDIS}^{\pi}$ term (Eq. 4), which acts as measure of the age of the water mass and has high values in old deep layers (see Table S1). These negative values of $\mathrm{C}_{\mathrm{ANT}} \mathrm{BC}$ were found at some points in deep waters of the section (mainly UCDW and LCDW layers) and were small (between 0 and $-2 \mu \mathrm{mol} \mathrm{kg}{ }^{-1}$, i.e. less than the accuracy of the methodology) and changed to zero for our analysis.

\subsection{Changes in the carbon system}

Changes in carbon system parameters $\left(\frac{\partial \mathrm{DIC}}{\partial t}, \frac{\partial \mathrm{TA}_{\mathrm{A}}}{\partial t}, \frac{\partial \mathrm{C}_{\mathrm{ANT}} \mathrm{BC}}{\partial t}, \frac{\partial \mathrm{pH}}{\partial t}\right.$ and $\left.\frac{\partial \Omega_{\mathrm{Ar}}}{\partial t}\right) \quad$ were estimated using linear regressions with time for the period 1995-2011 in each one of the water mass layers defined by their $\gamma^{\mathrm{n}}$ condition (Table 2). The trends were estimated using all the points in each water mass layer, and only those linear trends with $p<0.05$ and $r>=0.2$ were considered statistically 
significant for discussion. We show the value of the root mean square error (RMSE or square root of the variance of the residuals), which can be interpreted in large part as unexplained variance caused by short-timescale processes and the different seasonal timings of the cruises. RMSE has the same units as the response variable.

With respect to the total change in DIC $\left(\frac{\partial \mathrm{DIC}}{\partial t}\right)$, our goal is to disentangle the effects that solubility, circulation, biology and $\mathrm{C}_{\mathrm{ANT}}$ uptake have on the variability of DIC. The total change in DIC $\left(\frac{\partial \mathrm{DIC}}{\partial t}\right)$ in a water mass is due to changes in the atmosphere-ocean interchange, biological processes and circulation processes. In order to account for the change in DIC due the atmosphere-ocean interchange and biological processes, we compare $\frac{\partial \mathrm{DIC}}{\partial t}$ to $\frac{\partial \mathrm{C}_{\mathrm{ANT}_{\_} \mathrm{BC}}}{\partial t}$ and $\frac{\partial \mathrm{DIC}_{\mathrm{C}}^{\mathrm{BIO}}}{\partial t}$, Eq. (2). The change in DIC not explained by $\frac{\partial \mathrm{C}_{\mathrm{ANT}_{\mathrm{B}} \mathrm{BC}}}{\partial t}$ or $\frac{\partial \mathrm{DIC}}{\partial t}$ wiO will then be due to circulation processes.

In order to compare $\frac{\partial \mathrm{DIC}}{\partial t}$ to $\frac{\partial \mathrm{C}_{\mathrm{ANT}} \mathrm{BC}}{\partial t}$ we need to consider how the change in $\frac{\partial \mathrm{DIC}^{\mathrm{BIO}}}{\partial t}$ and $\mathrm{DIC}^{\pi}\left(\frac{\partial \mathrm{DIC}^{\pi}}{\partial t}\right)$ (terms of Eq. 1, Sect. 3.2) affect the changes in $\mathrm{C}_{\mathrm{ANT}} \mathrm{BC}$.

The term $\frac{\partial \mathrm{DIC}}{\partial t}^{\pi}$ can be expressed as follows:

$\frac{\partial \mathrm{DIC}^{\pi}}{\partial t}=\frac{\partial \mathrm{DIC}_{\mathrm{SAT}}^{\pi}}{\partial t}-\frac{\partial \mathrm{CDIS}^{\pi}}{\partial t}$.

The terms $\frac{\partial \mathrm{CDIS}}{\partial t}^{\pi}$ and $\frac{\partial \mathrm{DIC}_{\mathrm{SAT}}^{\pi}}{\partial t}$ reflect changes in the properties of the water masses over time, primarily temperature and salinity change due to mixing and heating or cooling. CDIS $^{\pi}$ and DIC SAT $^{\pi}$ are defined at the ocean surface (in each of the SWTs: Table S1) and are calculated at each point in the ocean interior using the OMP analysis (Sects. S2 and S3). Because a change in temperature and/or salinity in the water is solved by the OMP analysis as a change in the SWTs fractions, this also produces varying $\mathrm{CDIS}^{\pi}$ and $\mathrm{DIC}_{\mathrm{SAT}}^{\pi}$. No significant trends were obtained for CDIS $^{\pi}$ in any of the layers. $C_{\text {ANT_BC }}$ (Eq. 1) is not affected by the changes in solubility occurring from one voyage to another (thus neither is $\frac{\partial \mathrm{C}_{\mathrm{ANT} B \mathrm{BC}}}{\partial t}$ ), since any change in temperature or salinity is cancelled out by the subtraction of $\mathrm{DIC}^{\pi}$ with respect to DIC in Eq. (1) (Sect. 3.2) and by $\mathrm{O}_{2}$ respect to $\mathrm{O}_{\mathrm{SAT}}$ in the DIC ${ }^{\mathrm{BIO}}$ term (Eq. 2). However, $\frac{\partial \mathrm{DIC}}{\partial t}$ based on the measured DIC in the sections will be affected by changes in the solubility over time, and this difference needs to be accounted for when comparing $\frac{\partial \mathrm{DIC}}{\partial t}$ with $\frac{\partial \mathrm{C}_{\mathrm{ANT} B \mathrm{BC}}}{\partial t}$ to obtain a better approximation for the change in $\mathrm{C}_{\mathrm{ANT}}: \frac{\partial \mathrm{C}_{\mathrm{ANT}}}{\partial t}=\frac{\partial \mathrm{C}_{\mathrm{ANT}} \mathrm{BC}}{\partial t}+\frac{\partial \mathrm{DIC}}{\partial t}^{\pi}$.

The term $\frac{\partial \mathrm{DIC}^{\mathrm{BIO}}}{\partial t}$ can be influenced by changes with time of alkalinity due to changes in the rate of carbonate precipitation-dissolution and of AOU due to changes in the rate of remineralisation and in circulation. In the present study only surface waters of the SR03 section present changes DIC ${ }^{\text {BIO }}$ between 1995 and 2011. Numerous studies have reported a strong influence of biological communities in the seasonal cycle of dissolved $\mathrm{O}_{2}$ in surface waters (Bender
Table 3. Location of the ACC fronts south of Tasmania for each of the cruises following the definitions of Sokolov and Rintoul (2002) for hydrographic data. ${ }^{*}$ The range in the location of the SAF for the 2011 cruise could be related to a diversification of the PF or SAF into different jets (Sokolov and Rintoul, 2009) but also to crossing the meander of the front twice.

\begin{tabular}{lllll}
\hline Cruise & STF & SAF & PF & SACCF \\
\hline 1995 & $\sim 45.4^{\circ} \mathrm{S}$ & $\sim 51.8^{\circ} \mathrm{S}$ & $\sim 55.2^{\circ} \mathrm{S}$ & $\sim 63.8^{\circ} \mathrm{S}$ \\
2001 & $\sim 46.4^{\circ} \mathrm{S}$ & $\sim 50.1^{\circ} \mathrm{S}$ & $\sim 54.5^{\circ} \mathrm{S}$ & $\sim 63.7^{\circ} \mathrm{S}$ \\
2008 & $\sim 46.4^{\circ} \mathrm{S}$ & $\sim 52.2^{\circ} \mathrm{S}$ & $\sim 54.6^{\circ} \mathrm{S}$ & $\sim 63.5^{\circ} \mathrm{S}$ \\
2011 & $\sim 45^{\circ} \mathrm{S}$ & $\sim 52.16-50.5^{\circ} \mathrm{S}^{*}$ & $\sim 54.5^{\circ} \mathrm{S}$ & $\sim 63.4^{\circ} \mathrm{S}$ \\
\hline
\end{tabular}

et al., 1996; Moore and Abbott, 2000; Sambrotto and Mace, 2000; Trull et al., 2001a). Inter-annual variability in $\mathrm{O}_{2}$ in upper layers of the Southern Ocean have also been related to changes in the entrainment of deeper waters into the mixed layer due to the mixed layer depth variability (Matear et al., 2000; Verdy et al., 2007; Sabine et al., 2008; Sallée et al., 2012). Although some studies found long-term decreases in $\mathrm{O}_{2}$ due to circulation in deep waters of the Weddell Sea (van Heuven et al., 2014) and for the first $1000 \mathrm{~m}$ of the global ocean (Helm et al., 2011), significant long-term trends in $\mathrm{O}_{2}$ due to circulation and remineralisation processes have not yet been reported for surface waters of the Southern Ocean. Thus, the term $\frac{\partial \mathrm{DIC}}{\partial t}$ may also contribute to variation in $\frac{\partial \mathrm{C}_{\mathrm{ANT}} \mathrm{BC}}{\partial t}$, since part of the changes in $\mathrm{AOU}$ with time reflect changes in circulation that we cannot separate from those in remineralisation. We consider the best approximation for the change in $\mathrm{C}_{\mathrm{ANT}}$ as a range depending on the possible effect of biology and circulation processes on $\frac{\partial \mathrm{DIC} \text { BIO }}{\partial t}$. If the value of $\frac{\partial \mathrm{DIC} \mathrm{BIO}^{\mathrm{BIO}}}{\partial t}$ is due to the variability in the remineralisation rates and the change in solubility is considered, the estimate $\frac{\partial \mathrm{C}_{\text {ANT_BC}}}{\partial t}$ will be the lower limit of the range (lower limit of $\frac{\partial \mathrm{C}_{\mathrm{ANT}}}{\partial t}=\frac{\partial \mathrm{C}_{\mathrm{ANT}} \mathrm{BC}}{\partial t}+\frac{\partial \mathrm{DIC}}{\partial t}^{\pi}$ ). For the upper limit of the range, we consider that the value of $\frac{\partial \mathrm{DIC}}{\partial t}$ is due to changes in circulation and the upper limit of the range is obtained by $\frac{\partial \mathrm{C}_{\mathrm{ANT}}}{\partial t}=\frac{\partial \mathrm{C}_{\mathrm{ANT} B \mathrm{BC}}}{\partial t}+\frac{\partial \mathrm{DIC}}{\partial t}^{\pi}+\frac{\partial \mathrm{DIC}^{\mathrm{BIO}}}{\partial t}$. We assume that the changes in DIC ${ }^{\mathrm{BIO}}$ due to circulation do not affect the amount of DIC in the layer. This assumption is one of the caveats of the methodology, since we cannot know how much of the change in DIC is associated with changes in circulation, i.e. how much of the change in DIC is a change in nonanthropogenic DIC. We will discuss this more in Sect. 6.2.

\section{Results}

The different trends in biogeochemical properties are summarised in Table 4. The biogeochemical changes between 1995 and 2011 are presented for each of the water mass layers and the effect of changes in solubility, biological processes and circulation in the estimates of $\frac{\partial \mathrm{C}_{\mathrm{ANT}}}{\partial t}$ and $\frac{\partial \mathrm{DIC}}{\partial t}$ 
Table 4. Trends in the water mass layers for the period 1995-2011 of dissolved inorganic carbon ( $\partial \mathrm{DIC} / \partial t$ ), anthropogenic carbon $\left(\partial \mathrm{C}_{\mathrm{ANT}} / \partial t\right)$, silicate $\left(\partial \mathrm{SiO}_{4} / \partial t\right)$ total $\mathrm{pH}\left(\partial \mathrm{pH}_{\mathrm{T}} / \partial t\right)$, aragonite saturation $\left(\partial \Omega_{\mathrm{Ar}} / \partial t\right)$ and percentage of change in the aragonite saturation $\left(\% \partial \Omega_{\mathrm{Ar}} / \partial t\right)$. RMSE = root mean square error. ${ }^{*}$ Trends in $\mathrm{C}_{\mathrm{ANT}}$ for the AASW and AASW upw layers considering an approximate value for the increase in DIC due to the advection of old deep waters to the section (see Sect. 4.4 .1 in the text). ${ }^{* *}$ The value of $\frac{\partial \mathrm{C}_{\mathrm{ANT}}}{\partial t}$ in the AABW layer is considered negligible because it falls below the accuracy of the back-calculation method.

\begin{tabular}{|c|c|c|c|c|c|c|}
\hline \multirow[t]{2}{*}{ Layer } & $\begin{array}{l}\partial \mathrm{DIC} / \partial t \\
\left(\mu \mathrm{mol} \mathrm{kg}{ }^{-1} \mathrm{yr}^{-1}\right)\end{array}$ & $\begin{array}{l}\partial \mathrm{C}_{\mathrm{ANT}} / \partial t \\
\left(\mu \mathrm{mol} \mathrm{kg}-1 \mathrm{yr}^{-1}\right)\end{array}$ & $\begin{array}{l}\partial \mathrm{SiO}_{4} / \partial t \\
\left(\mu \mathrm{mol} \mathrm{kg}{ }^{-1} \mathrm{yr}^{-1}\right)\end{array}$ & $\begin{array}{l}\partial \mathrm{pH}_{\mathrm{T}} / \partial t \\
\left(\mathrm{yr}^{-1}\right)\end{array}$ & $\begin{array}{l}\partial \Omega_{\mathrm{Ar}} / \partial t \\
\left(\mathrm{yr}^{-1}\right)\end{array}$ & $\begin{array}{l}\% \\
\partial \Omega_{\mathrm{Ar}} / \partial t \\
\left(\% \mathrm{yr}^{-1}\right)\end{array}$ \\
\hline & 1995-2011 & $1995-2011$ & $1995-2011$ & 1995-2011 & 1995-2011 & $1995-2011$ \\
\hline \multirow[t]{2}{*}{ STCW } & $\begin{array}{l}0.86 \pm 0.07 \\
\mathrm{RMSE}=7\end{array}$ & {$[0.71 \pm 0.08-0.93 \pm 0.08]$} & - & $-0.0027 \pm 0.0001$ & $-0.009 \pm 0.001$ & $-0.42 \pm 0.17$ \\
\hline & & & & $\mathrm{RMSE}=0.01$ & $\mathrm{RMSE}=0.15$ & \\
\hline \multirow[t]{2}{*}{ AASW } & $\begin{array}{l}0.85 \pm 0.14 \\
\text { RMSE }=21\end{array}$ & $\begin{array}{l}{[0.35 \pm 0.14-0.85 \pm 0.21]} \\
*[0.35 \pm 0.14-0.65 \pm 0.21]\end{array}$ & - & $-0.0035 \pm 0.0002$ & $-0.009 \pm 0.001$ & $-0.61 \pm 0.19$ \\
\hline & & & & $\mathrm{RMSE}=0.03$ & $\mathrm{RMSE}=0.14$ & \\
\hline \multirow[t]{2}{*}{ AASW $_{\text {upw }}$} & $\begin{array}{l}0.61 \pm 0.10 \\
\text { RMSE }=9\end{array}$ & $\begin{array}{l}{[0-0.41 \pm 0.16]} \\
*[0-0.21 \pm 0.16]\end{array}$ & $\begin{array}{l}0.36 \pm 0.06 \\
\text { RMSE }=6\end{array}$ & $-0.0015 \pm 0.0004$ & - & - \\
\hline & & & & $\mathrm{RMSE}=0.04$ & & \\
\hline \multirow[t]{2}{*}{ SAMW } & $\begin{array}{l}1.10 \pm 0.14 \\
\mathrm{RMSE}=16\end{array}$ & $\begin{array}{l}0.92 \pm 0.09 \\
\mathrm{RMSE}=10\end{array}$ & - & $-0.0031 \pm 0.0003$ & $-0.011 \pm 0.001$ & $-0.67 \pm 0.20$ \\
\hline & & & & $\mathrm{RMSE}=0.03$ & $\mathrm{RMSE}=0.17$ & \\
\hline \multirow[t]{2}{*}{ AAIW } & $\begin{array}{l}0.40 \pm 0.15 \\
\mathrm{RMSE}=24\end{array}$ & $\begin{array}{l}0.42 \pm 0.06 \\
\mathrm{RMSE}=10\end{array}$ & - & & - & - \\
\hline & & & & $\mathrm{RMSE}=0.03$ & & \\
\hline \multirow[t]{2}{*}{ UCDW } & $\begin{array}{l}0.29 \pm 0.02 \\
\mathrm{RMSE}=5\end{array}$ & - & $\begin{array}{l}0.22 \pm 0.04 \\
\mathrm{RMSE}=12\end{array}$ & $-0.0012 \pm 0.0001$ & - & - \\
\hline & & & & $\mathrm{RMSE}=0.03$ & & \\
\hline \multirow[t]{2}{*}{ LCDW } & $\begin{array}{l}0.20 \pm 0.02 \\
\mathrm{RMSE}=4\end{array}$ & - & $\begin{array}{l}0.27 \pm 0.02 \\
\mathrm{RMSE}=4\end{array}$ & & - & - \\
\hline & & & & $\mathrm{RMSE}=0.03$ & & \\
\hline AABW & $\begin{array}{l}0.24 \pm 0.02 \\
\mathrm{RMSE}=2\end{array}$ & $\begin{array}{l}* * 0.07 \pm 0.01 \\
\mathrm{RMSE}=2\end{array}$ & $\begin{array}{l}0.15 \pm 0.05 \\
\mathrm{RMSE}=11\end{array}$ & - & - & - \\
\hline
\end{tabular}

are considered along with changes in the aragonite saturation depth and $\mathrm{C}_{\mathrm{ANT}}$ storage.

\subsection{Changes in DIC, $\mathrm{C}_{\mathrm{ANT}}$ and $\mathrm{pH}_{\mathrm{T}}(\mathbf{1 9 9 5}-2011)$.}

\subsubsection{Upper ocean layers (STCW, AASW and $\mathbf{A A S W}_{\text {upw }}$ )}

In the STCW layer, DIC increased between 1995 and 2011 (Fig. 2a, b) at a rate of $0.86 \pm 0.07 \mu \mathrm{mol} \mathrm{kg}^{-1} \mathrm{yr}^{-1}$ ( $\frac{\partial \text { DIC }}{\partial t}$, Table 4$)$, leading to a decrease in $\mathrm{pH}_{\mathrm{T}}$ of $-0.0027 \pm 0.0001 \mathrm{yr}^{-1} \quad\left(\frac{\partial p H_{\mathrm{T}}}{\partial t}\right.$, Table 4, Fig. 2e, f $)$. The trend in $\mathrm{pH}_{\mathrm{T}}$ is similar to the one found by Lauvset et al. (2015) between 1991 and 2011 for the IO-STPS (Indian Ocean subtropical permanently stratified) biome $\left(-0.0027 \pm 0.0005 \mathrm{yr}^{-1}\right)$. We found a decrease in $\mathrm{DIC}^{\pi}$ $\left(\frac{\partial \mathrm{DIC}}{\partial t}^{\pi}=-0.34 \pm 0.06 \mu \mathrm{molkg}^{-1} \mathrm{yr}^{-1}\right.$, Table 5) in the STCW layer due to a negative trend of $\mathrm{DIC}_{\mathrm{SAT}}^{\pi}$ resulting from a decrease in solubility that resulted from a temperature increase (calculated from the section data) in the STCW layer of $0.0335 \pm 0.0130{ }^{\circ} \mathrm{C} \mathrm{yr}^{-1}$ (not shown). The increase in temperature agrees with the warming trend observed south of Tasmania of 0.2 to $0.3{ }^{\circ} \mathrm{C}$ decade $^{-1}$, obtained from satellite data (Armour and Bitz, 2015) and from combined data and models $\left(0.5^{\circ} \mathrm{C}\right.$ every 30 years, Aoki et al., 2015). For $\theta=16^{\circ} \mathrm{C}$ and $\mathrm{S}=35.1$ (definition of $\mathrm{SWT}_{\mathrm{STW} 16}$ in the OMP analysis, Table S1), a change in temperature of $0.03{ }^{\circ} \mathrm{C} \mathrm{yr}^{-1}$ would lead to a decrease in $\mathrm{DIC}_{\mathrm{SAT}}^{\pi}$ of $-0.27 \mu \mathrm{mol} \mathrm{kg} \mathrm{yr}^{-1}$, which is similar to the value obtained for $\frac{\partial D I C}{\partial t}^{\pi}$ in the STCW layer (Table 5). The difference between these trends is related to the mixing of the different SWT fractions within the STCW layer, established from the OMP analysis (see Sect. 3 and Sect. S2). When the solubility change is incorporated into $\frac{\partial \mathrm{C}_{\mathrm{ANT}} \mathrm{BC}}{\partial t}$, i.e. $\frac{\partial \mathrm{C}_{\mathrm{ANT} B \mathrm{BC}}}{\partial t}+\frac{\partial \mathrm{DIC}}{\partial t}^{\pi}$ (Table 5, Fig. 2c, d), we obtain a value of $0.71 \stackrel{\partial t}{ \pm} 0.08 \mu \mathrm{mol} \mathrm{kg} \mathrm{mr}^{-1} \mathrm{yr}^{-1}$. 
Table 5. Trends of anthropogenic carbon from estimates of the back-calculation method and of the terms DIC ${ }^{\text {BIO }}$ and DIC ${ }^{\pi}$ (see Sect. 3.2 of the text). RMSE $=$ root mean square error. Bottom: schematic of the estimation of the upper and lower limits of $\frac{\partial \mathrm{C}_{\mathrm{ANT}}}{\partial t}$ (see Sect. 3.3).

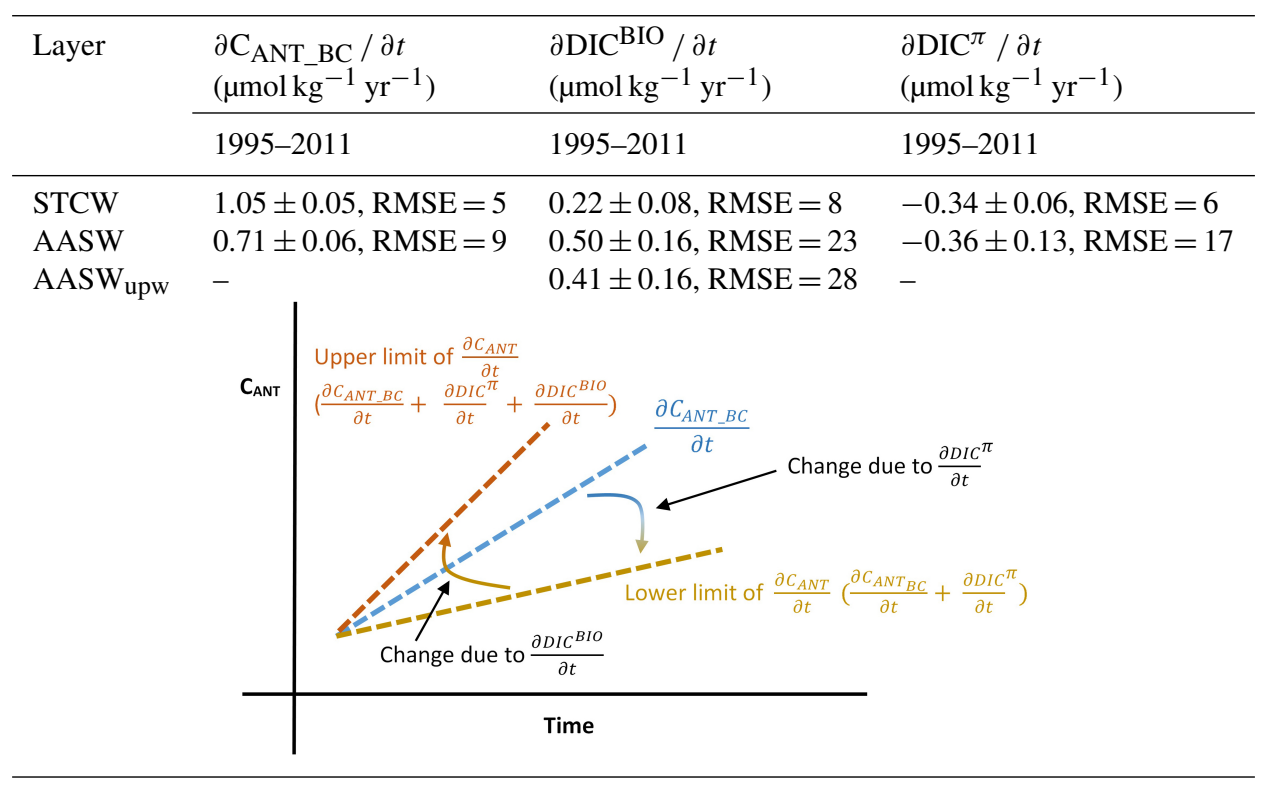
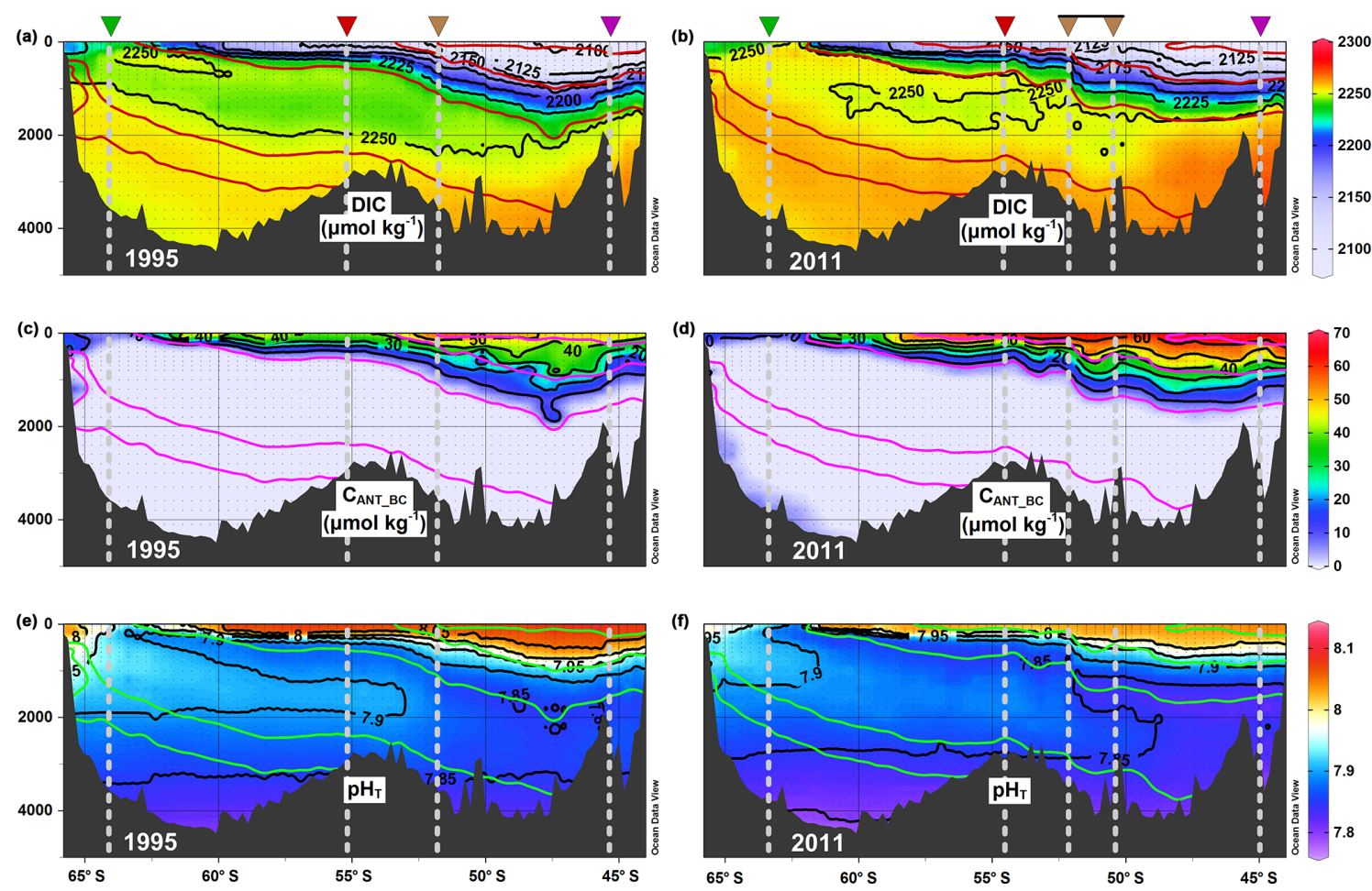

Figure 2. Distribution of DIC (a, b), $\mathrm{C}_{\mathrm{ANT} \_\mathrm{BC}}(\mathbf{c}, \mathbf{d})$ and $\mathrm{pH}_{\mathrm{T}}(\mathbf{e}, \mathbf{f})$ in the SR03 section south of Tasmania for the years $1995(\mathbf{a}, \mathbf{c}, \mathbf{e})$ and 2011 (b, d, f). Red lines in plots (a) and (b), pink lines in plots (c) and (d), and green lines in plots (e) and (f) indicate the neutral surfaces that define the different water masses $\left(\gamma^{n}\right)$. The position of the fronts (coloured triangles and grey dotted lines) in each of the cruises is also shown. 
There is an increase in $\mathrm{DIC}^{\mathrm{BIO}}$ in the $\mathrm{STCW}$ layer $\left(\frac{\partial \mathrm{DIC}^{\mathrm{BIO}}}{\partial t}\right.$, Table 5) that also affects the estimates of $\frac{\partial \mathrm{C}_{\mathrm{ANT} B \mathrm{BC}}}{\partial t}$. The increase in $\mathrm{DIC}^{\mathrm{BIO}}$ is due to an increase in AOU (no changes were found in TA, Eq. 2 in Sect. 3.2) due to a decrease in $\mathrm{O}_{2}$ in the layer. We cannot separate the effects of circulation and biology on the AOU change, and $\frac{\partial \mathrm{C}_{\mathrm{ANT}}}{\partial t}$ in Table 4 should be considered a range. If the changes in AOU are only due to the variability in the remineralisation rates, the calculated lower limit of $\frac{\partial \mathrm{C}_{\mathrm{ANT}}}{\partial t}$ is $0.71 \pm 0.08 \mu \mathrm{mol} \mathrm{kg}^{-1} \mathrm{yr}^{-1}$ (Table 4, $\frac{\partial \mathrm{C}_{\mathrm{ANT}}}{\partial t}=\frac{\partial \mathrm{C}_{\mathrm{ANT} B \mathrm{BC}}}{\partial t}+\frac{\partial \mathrm{DIC}^{\pi}}{\partial t}$ in Table 5). If the changes in AOU are due to changes in circulation, the upper limit value of $0.93 \pm 0.11 \mu \mathrm{mol} \mathrm{kg}^{-1} \mathrm{yr}^{-1}$ $\left(\frac{\partial \mathrm{C}_{\mathrm{ANT}}}{\partial t}=\frac{\partial \mathrm{C}_{\mathrm{ANT}} \mathrm{BC}}{\partial t}+\frac{\partial \mathrm{DIC}^{\pi}}{\partial t}+\frac{\partial \mathrm{DIC}^{\mathrm{BIO}}}{\partial t}\right)$ will explain the increase in DIC in the STCW layer $\left(\frac{\partial \mathrm{DIC}}{\partial t} \approx \frac{\partial \mathrm{C}_{\mathrm{ANT}}}{\partial t}\right.$, Table 4$)$. The increase in $\mathrm{C}_{\mathrm{ANT}}$ found in this layer is comparable to the range of increases $\left(0.8-1.3 \mu \mathrm{mol} \mathrm{kg}{ }^{-1} \mathrm{yr}^{-1}\right)$ found by Carter et al. (2017) in the Pacific Ocean (P16 WOCE, CLIVAR and GOSHIP lines) for the past 2 decades (1990s-2000s and 2000s-2010s).

Changes in the AASW layer are summarised in Table 4. DIC increased at a similar rate of $0.85 \pm 0.14 \mu \mathrm{mol} \mathrm{kg}^{-1} \mathrm{yr}^{-1}$ to the STCW layer and the trend is similar to the values found by Williams et al. (2015) for the AASW layer in the Pacific sector of the Southern Ocean $(12-18 \mu \mathrm{mol} \mathrm{kg}-1$ for the period $1992-2011$ and $3-5 \mu \mathrm{mol} \mathrm{kg}^{-1}$ for the period 2005-2011). The increase in DIC in the AASW layer results in a $\mathrm{pH}_{\mathrm{T}}$ decrease of $-0.0035 \pm 0.0002 \mathrm{yr}^{-1}$, close to Williams et al. (2015) estimates for surface waters $\left(\sim-0.0023 \pm 0.0009 \mathrm{yr}^{-1}\right)$ and Lauvset et al. (2015) estimates of $-0.0021 \pm 0.0002 \mathrm{yr}^{-1}$ for the Southern Ocean seasonally stratified, SO-SPSS, biome. The AASW layer for our sections warmed at a similar rate $\left(0.0369 \pm 0.0109^{\circ} \mathrm{C} \mathrm{yr}^{-1}\right)$ to the STCW layer, reducing the solubility and influencing $\frac{\partial \mathrm{DIC}}{\partial t}^{\pi}$ (Table 5) due to changes in $\mathrm{DIC}_{\mathrm{SAT}}^{\pi}$. The $\mathrm{DIC}^{\mathrm{BIO}}$ also increased with time $\left(0.50 \pm 0.16 \mu \mathrm{mol} \mathrm{kg}^{-1} \mathrm{yr}^{-1}\right.$, Table 5) due to an increase in AOU. Following the same reasoning as for the STCW layer and considering the trend in $\mathrm{C}_{\text {ANT }}$ of $0.70 \pm 0.06 \mu \mathrm{mol} \mathrm{kg}^{-1} \mathrm{yr}^{-1}$ obtained by the backcalculation method $\left(\frac{\partial \mathrm{C}_{\mathrm{ANT}_{2} \mathrm{BC}}}{\partial t}\right.$; Table 5), the best estimation of $\frac{\partial \mathrm{C}_{\mathrm{ANT}}}{\partial t}$ in the AASW layer is a range of $0.35 \pm 0.14$ to $0.85 \pm 0.22 \mu \mathrm{mol} \mathrm{kg}^{-1} \mathrm{yr}^{-1}$ (Table 4). Our values are within the range of values found by Williams et al. (2015) for the AASW in the Pacific sector between 2005 and 2011, and the upper limit is similar to a $\mathrm{C}_{\mathrm{ANT}}$ increase of 0.73 $0.86 \mu \mathrm{mol} \mathrm{kg} \mathrm{gr}^{-1} \mathrm{yr}^{-1}$ for waters South of Tasmania for the period 1968-1996 found by McNeil et al. (2001).

DIC in the $\mathrm{AASW}_{\text {upw }}$ layer increased at a rate of $0.61 \pm 0.10 \mu \mathrm{mol} \mathrm{kg}^{-1} \mathrm{yr}^{-1}$, and the $\mathrm{pH}_{\mathrm{T}}$ decreased by $-0.0015 \pm 0.0004 \mathrm{yr}^{-1}$ (Table 4). We were not able to detect a statistically significant trend in $\mathrm{DIC}^{\pi}$ (i.e. solubility) or $\mathrm{C}_{\mathrm{ANT}}$ from the estimates of the back-calculation method $\left(\frac{\partial \mathrm{C}_{\mathrm{ANT}} \mathrm{BC}}{\partial t}\right.$ Table 5). However, we found an increase in $\mathrm{DIC}^{\mathrm{BIO}}$ of $0.42 \pm 0.28 \mu \mathrm{mol} \mathrm{kg}^{-1} \mathrm{yr}^{-1}$ (Table 5) that is due to an increase in AOU. Considering the different drivers of the AOU increase (e.g. biology, circulation), the optimal estimation of $\frac{\partial \mathrm{C}_{\mathrm{ANT}}}{\partial t}$ for this layer is a value between 0 and $0.42 \pm 0.28 \mu \mathrm{mol} \mathrm{kg}^{-1} \mathrm{yr}^{-1}$ (Table 4).

\subsubsection{Mode waters and intermediate layers (SAMW and AAIW)}

The increase in DIC in the SAMW layer $\left(1.10 \pm 0.14 \mu \mathrm{mol} \mathrm{kg}^{-1} \mathrm{yr}^{-1}\right)$ for the period 1995-2011 is higher than that of upper ocean layers, and $\mathrm{pH}_{\mathrm{T}}$ decreases over the same period by $-0.0031 \pm 0.0003 \mathrm{yr}^{-1}$ (Table 4). The DIC increase is explained almost entirely by $\frac{\partial \mathrm{C}_{\mathrm{ANT}} \mathrm{BC}}{\partial t}$ of $0.92 \pm 0.09 \mu \mathrm{mol} \mathrm{kg}{ }^{-1} \mathrm{yr}^{-1}$. No significant trend was found in $\mathrm{DIC}^{\mathrm{BIO}}$ or $\mathrm{DIC}^{\pi}$ (i.e, $\left.\frac{\partial \mathrm{C}_{\mathrm{ANT}}}{\partial t}=\frac{\partial \mathrm{C}_{\mathrm{ANT}} \mathrm{BC}}{\partial t}\right)$. In the AAIW layer the DIC trend of $0.40 \pm 0.15 \mu \mathrm{mol} \mathrm{kg}^{-1} \mathrm{yr}^{-1}$ results in a $\mathrm{pH}_{\mathrm{T}}$ decrease of $-0.0017 \pm 0.0002 \mathrm{yr}^{-1}$ and is also explained by the increase in $\mathrm{C}_{\mathrm{ANT}}(0.42 \pm 0.06 \mu \mathrm{mol} \mathrm{kg}-1$ $\mathrm{yr}^{-1}, \frac{\partial \mathrm{C}_{\mathrm{ANT}}}{\partial t}=\frac{\partial \mathrm{C}_{\mathrm{ANT}} \mathrm{BC}}{\partial t}$, Tables 4 and 5). As with SAMW, no changes in solubility $\left(\frac{\partial \mathrm{DIC}^{\pi}}{\partial t}\right)$ or biology/circulation processes $\left(\frac{\partial \mathrm{DIC} \mathrm{C}^{\mathrm{BIO}}}{\partial t}\right)$ were detected in the AAIW layer. The values found in the SAMW and AAIW layers are very similar to the mean decadal changes found by Murata et al. (2007) between the 1990s and the 2000s in the subtropical Pacific Ocean $\left(\sim 1 \mu \mathrm{mol} \mathrm{kg}^{-1} \mathrm{yr}^{-1}\right.$ for the SAMW layer and $0.4 \mu \mathrm{mol} \mathrm{kg}^{-1} \mathrm{yr}^{-1}$ for the AAIW). Waters et al. (2011) used data from the $\mathrm{P} 18$ line along $\sim 110^{\circ} \mathrm{W}$ and estimated an increase in $\mathrm{C}_{\mathrm{ANT}}$ of $0.89 \pm 0.4 \mu \mathrm{mol} \mathrm{kg} \mathrm{gr}^{-1}$ for the SAMW and $0.64 \pm 0.2 \mu \mathrm{mol} \mathrm{kg} \mathrm{yr}^{-1}$ in AAIW for the period 1994-2008, which are also comparable to our results.

\subsubsection{Deep-bottom layers (UCDW, LCDW and AABW)}

The UCDW layer shows an increase in DIC of $0.29 \pm 0.02 \mu \mathrm{mol} \mathrm{kg}^{-1} \mathrm{yr}^{-1}$ between 1995 and 2011 and a change in $\mathrm{pH}_{\mathrm{T}}$ of $-0.0013 \pm 0.0001 \mathrm{yr}^{-1}$, which is similar to the change in DIC $\left(0.20 \pm 0.02 \mu \mathrm{mol} \mathrm{kg}{ }^{-1} \mathrm{yr}^{-1}\right)$ and $\mathrm{pH}_{\mathrm{T}}\left(-0.0012 \pm 0.0002 \mathrm{yr}^{-1}\right)$ for LCDW. No statistically significant changes in time were detected for $\mathrm{C}_{\mathrm{ANT}} \mathrm{BC}$ or in the DIC ${ }^{\mathrm{BIO}}$ and $\mathrm{DIC}^{\pi}$ terms for any of these two layers.

The AABW layer also shows an increase in DIC $\left(0.24 \pm 0.02 \mu \mathrm{mol} \mathrm{kg}^{-1} \mathrm{yr}^{-1}\right)$ during the period 1995-2011 with an associated decrease in $\mathrm{pH}_{\mathrm{T}}$ of $-0.0013 \pm 0.0002$ $\mathrm{yr}^{-1}$ (Table 4). The increase in $\mathrm{C}_{\mathrm{ANT}}\left(\frac{\partial \mathrm{C}_{\mathrm{ANT}} \mathrm{BC}}{\partial t}\right)$ of $0.07 \pm 0.01 \mu \mathrm{mol} \mathrm{kg}{ }^{-1} \mathrm{yr}^{-1}$ is low and this trend indicates an increase in $C_{\text {ANT }}$ of $\sim 1 \mu \mathrm{mol} \mathrm{kg}-1$, which is less than the accuracy of the back-calculation method $\left( \pm 6 \mu \mathrm{mol} \mathrm{kg}{ }^{-1}\right)$. 
Table 6. Approximated rates of $\mathrm{C}_{\mathrm{ANT}}$ storage based on the trends from Table 4.

\begin{tabular}{|c|c|c|}
\hline Layers & $\begin{array}{l}\text { Thickness } \\
\text { (m) }\end{array}$ & $\begin{array}{l}\mathrm{C}_{\mathrm{ANT}} \text { storage rates } \\
\left(\mathrm{mol} \mathrm{m}^{-2} \mathrm{yr}^{-1}\right)\end{array}$ \\
\hline STCW & 230 & {$[0.17 \pm 0.06-0.22 \pm 0.08]$} \\
\hline AASW & 280 & {$[0.10 \pm 0.04-0.24 \pm 0.07]$} \\
\hline AASW $_{\text {upw }}$ & 275 & {$[0-0.11 \pm 0.04]$} \\
\hline SAMW & 450 & $0.43 \pm 0.14$ \\
\hline AAIW & 900 & $0.39 \pm 0.14$ \\
\hline SR03 section & - & $0.30 \pm 0.24$ \\
\hline
\end{tabular}

\subsection{Changes in the aragonite saturation $\left(\frac{\partial \Omega_{\mathrm{Ar}}}{\partial t}\right)$ and $\mathrm{C}_{\text {ANT }}$ storage}

There are statistically significant decreases in $\Omega_{\mathrm{Ar}}$ in the STCW, AASW and SAMW layers $\left(\sim-0.010 \pm 0.001 \mathrm{yr}^{-1}\right.$, Table 4) similar to the trends observed at open-ocean time series sites in recent decades (Bates et al., 2014). The decrease in $\Omega_{\mathrm{Ar}}$ found for the AASW layer $\left(-0.61 \pm 0.19 \% \mathrm{yr}^{-1}\right.$, Table 4) is also similar to the values obtained by Williams et al. (2015) for the Pacific sector of the Southern Ocean $\left(-0.47 \pm 0.10 \% \mathrm{yr}^{-1}\right.$ for the period 1992-2011 and $-0.50 \pm 0.20 \% \mathrm{yr}^{-1}$ for the period 2005-2011). Accompanying the decrease in $\Omega_{\mathrm{Ar}}$ with time along SR03 is the shoaling of the aragonite saturation depth (ASD, $\Omega_{\mathrm{Ar}}=1$, Fig. 3) at a mean rate of $-13 \pm 3 \mathrm{~m} \mathrm{yr}^{-1}$. The shoaling of the ASD is not uniform over the section. North of the PF, the ASD shoals at a rate of $-6 \pm 4 \mathrm{~m} \mathrm{yr}^{-1}$ while the rate is 3.5 times greater south of the PF $\left(-21 \pm 4 \mathrm{~m} \mathrm{yr}^{-1}\right)$. North of the PF the shoaling mostly affects the AAIW layer (Fig. 3a). South of the PF, from $\sim 62^{\circ} \mathrm{S}$, the movement of the ASD follows the upwelling path of the UCDW layer (Fig. 3) with a shoaling of $\sim 340 \mathrm{~m}$ over the 16 -year period.

The storage rate of $\mathrm{C}_{\mathrm{ANT}}$ (Table 6) for the surface and intermediate water mass layers is obtained from $\frac{\partial \mathrm{C}_{\mathrm{ANT}}}{\partial t}$ (Table 4), with the most storage in SAMW and AAIW due to both their greater thickness and $\frac{\partial \mathrm{C}_{\mathrm{ANT}}}{\partial t}$ values. The rate of increase of the $\mathrm{C}_{\mathrm{ANT}}$ storage in the whole longitude band of the SR03 section is $0.30 \pm 0.24 \mathrm{~mol} \mathrm{~m}^{-2} \mathrm{yr}^{-1}$, calculated by computing the mean of the storage rates of the layers weighted by the mean volume occupied by each of the layers for the period 1995-2011 (Table 6)

\section{Discussion}

Our results are indicative of a scenario of increased transport of deep waters into the section and enhanced upwelling at high latitudes for the period between 1995 and 2011 linked to strong westerly winds. Several studies have reported a trend in the Southern Annular Mode (SAM) toward its positive phase from the 1960s until the 2000s (Thompson and Solomon, 2002; Marshall, 2002, 2003; Lenton and Matear,

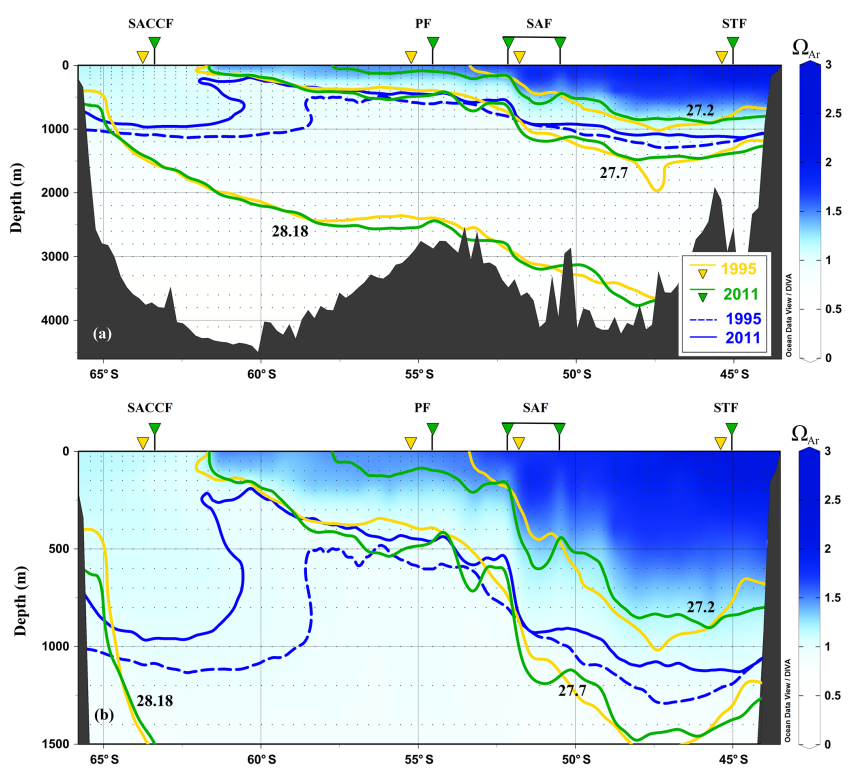

Figure 3. Aragonite saturation depth (ASD, $\left.\Omega_{\mathrm{Ar}}=1\right)$ for the 1995 and 2011 cruises. (a) Distribution of ASD (blue dotted and solid lines) and $\gamma^{\mathrm{n}}$ (green and yellow lines) in latitude in the SR03 section. (b) Section zoomed for the first $1500 \mathrm{~m}$ of the water column. The position of the fronts (triangles) in 1995 (yellow) and 2011 (green) is also shown. The blue palette in the background indicates the distribution of $\Omega_{\mathrm{Ar}}$ for the 2011 cruise.

2007; Sallée et al., 2008). According to these studies, the positive phase of the SAM is correlated with an intensification and southward movement of the subpolar westerly winds that ultimately lead to the enhancement of northward Ekman transport, meridional overturning and upwelling south of the ACC. Also, surface warming and more intense and frequent pulses in the extension of the EAC on long timescales have been related to a poleward movement of the westerly winds (Rintoul and Sokolov, 2001; Ridgway, 2007; Hill et al., 2011). From the 2000s on, the SAM index no longer presents a positive trend but, despite exhibiting considerable inter-annual variability (Fig. S2), remains in its positive phase, favouring strong winds over the region.

In the northern part of the SR03 section, the area occupied by the STCW has high variability due to the encounter between the EAC and the ZC in the north of the section (Ridgway et al., 2007; Herraiz-Borreguero and Rintoul, 2011; Sloyan et al., 2016). The warming of the STCW layer found in this study $\left(0.0335 \pm 0.0130^{\circ} \mathrm{C} \mathrm{yr}^{-1}\right)$ could be linked to variability in the extension of subtropical waters but it could also be related to atmospheric warming. Aoki et al. (2015) related the 30-year warming found north of the SAF in the South Pacific and Indian oceans to the intensification of the subtropical gyres, which promote the arrival of warmer waters. In the AASW layer that extends approximately between the SAF and the PF we found a similar warming $\left(0.0369 \pm 0.0109{ }^{\circ} \mathrm{C} \mathrm{yr}^{-1}\right)$ to that of the STCW. 
This could indicate that the increase in temperature found in the upper layers of the section could be most likely due to ocean heat uptake and atmospheric warming.

Due to the surface warming, the increase in DIC found in the STCW layer (Table 4) is lower than expected from the increase in atmospheric $\mathrm{CO}_{2}\left(\sim 1 \pm 0.12 \mu \mathrm{mol} \mathrm{kg}^{-1} \mathrm{yr}^{-1}\right)$. Nevertheless, at least $83 \%$ of the increase in DIC in the STCW layer is explained by the increase in $\mathrm{C}_{\mathrm{ANT}}$ (Table 4). As for the AASW layer, our results indicate that temperature does affect the estimate of $\frac{\partial \mathrm{DIC}}{\partial t}$, but the effect of the increase in $\mathrm{DIC}^{\mathrm{BIO}}$ (due to an increase in $\mathrm{AOU}$ ) overweigh that of solubility (Table 5).

The seasonal to inter-annual variability of the AASW layer is also influenced by the variability of the positions of the SAF and PF (Fig. 1, Table 3), which is highly conditioned by the flow of the ACC over the South-East Indian Ridge (Fig. 1). A close relationship between phytoplankton blooms and regions where the ACC fronts interact with large topographic features has been noticed (Moore et al., 1999; Moore and Abbott, 2000). A variability in the remineralisation rates due to phytoplankton bloom variability could explain the changes in $\mathrm{DIC}^{\mathrm{BIO}}$ observed in the AASW layer. Nevertheless, no changes in nutrients (nitrates or phosphates) are measurable in this layer that could indicate intense biological activity.

Furthermore, the AASW layer is also affected by the upwelling of deep waters south of the PF, and an intensification of the upwelling could increase the content of low- $\mathrm{O}_{2}$ DIC-rich waters in the AASW layer, leading to an increase in AOU. The increase in $\mathrm{DIC}^{\mathrm{BIO}}$ found in the $\mathrm{AASW}_{\text {upw }}$ layer (Table 4), south of the PF, is similar to the increase obtained for the AASW layer, which indicates the likelihood that the upwelling of deep waters results in the increase in AOU. The increase in $\mathrm{DIC}^{\mathrm{BIO}}$ in the $\mathrm{AASW}_{\text {upw }}$ layer coincides with an increase in salinity of $0.0029 \pm 0.0001 \mathrm{yr}^{-1}$ (not shown), which is consistent with increased transport of saltier waters from the deep ocean to subsurface layers. Besides, we also found an increase in dissolved silicate of $0.36 \pm 0.06 \mu \mathrm{mol} \mathrm{kg}^{-1} \mathrm{yr}^{-1}\left(\frac{\partial \mathrm{SiO}_{4}}{\partial t}\right.$ Table 4$)$ that could be related to the upwelling enhancement as well (Tréguer, 2014).

The influence of the upwelling on the DIC budgets (as non-anthropogenic DIC) is clearer in the $\mathrm{AASW}_{\text {upw }}$ layer than in the AASW layer. For the AASW layer, the lower limit of $\frac{\partial \mathrm{C}_{\mathrm{ANT}}}{\partial t}$ (i.e. the change in DIC ${ }^{\mathrm{BIO}}$ is assumed to be due to biological processes, Table 4) indicates that at least $41 \%$ of the increase in DIC in the layer is explained by the increase in $\mathrm{C}_{\mathrm{ANT}}$ while the lower limit of $\frac{\partial \mathrm{C}_{\mathrm{ANT}}}{\partial t}$ is zero for $\mathrm{AASW}_{\text {upw }}$ (Table 4), meaning that the effect of the upwelling over AASW is lower than over $\mathrm{AASW}_{\text {upw }}$. Matear and Lenton (2008), using carbon models, concluded that the uptake of $\mathrm{CO}_{2}$ by the waters north of the PF is more influenced by the wind variability than by other processes such as the upwelling. An intensification of the winds (due to a posi- tive phase in SAM) could contribute to the increase in $\mathrm{C}_{\mathrm{ANT}}$ found in the AASW layer. Considering the upper limits of $\frac{\partial \mathrm{C}_{\mathrm{ANT}}}{\partial t}$ in both layers (i.e. the change in DIC ${ }^{\mathrm{BIO}}$ is assumed to be due to circulation processes), the increase in $\mathrm{C}_{\mathrm{ANT}}$ in the $\mathrm{AASW}_{\text {upw }}$ layer represents no more than $69 \%$ of the increase in DIC (upper limit of $\frac{\partial \mathrm{C}_{\mathrm{ANT}}}{\partial t}$, Table 4), while the upper limit of $\frac{\partial \mathrm{C}_{\mathrm{ANT}}}{\partial t}$ for the AASW equals the increase in DIC.

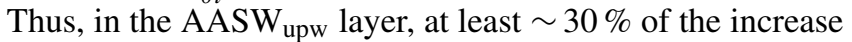
in DIC $\left(\sim 0.18 \mu \mathrm{mol} \mathrm{kg}^{-1} \mathrm{yr}^{-1}\right)$ is still not explained and is most probably related to the upwelling of DIC-rich waters. The increase in non-anthropogenic DIC could be even higher, since we assume that the change in $\mathrm{DIC}^{\mathrm{BIO}}$ due to circulation does not affect DIC (see Sect. 3.3).

In terms of the change in oxygen, Helm et al. (2011) found an average decrease in the concentration of $\mathrm{O}_{2}$ between 100 and $1000 \mathrm{~m}$ from 1970 to 1992 of $\sim-0.23 \mu \mathrm{mol} \mathrm{L}^{-1}$ for the Southern Ocean $(27 \%$ of the estimated global average change, $-0.93 \pm 0.23 \mu \mathrm{mol} \mathrm{L}^{-1}$ ). Considering the volume of the first $1000 \mathrm{~m}$ of the water column of the Southern Ocean to be $19400 \times 10^{-9} 1$ (obtained using ETOPO1, Amante and Eakins, 2009) and the volume of the first $1000 \mathrm{~m}$ of the SR03 section to be $2700 \times 10^{-9} 1$, the decrease in $\mathrm{O}_{2}$ found by Helm et al. (2011), if constant in time, would correspond to a decrease of $\sim-1.7 \mu \mathrm{mol} \mathrm{L}^{-1} \mathrm{yr}^{-1}$. We only found changes in oxygen within the surface water mass layers (STCW, AASW and $\mathrm{AASW}_{\text {upw }}$ ) that approximately fill the first $300 \mathrm{~m}$ of the water column of the SR03. Then, the decrease of $\sim-1.7 \mu \mathrm{mol} \mathrm{L}{ }^{-1}$ would correspond to an average change in $\mathrm{O}_{2}$ of $\sim-0.32 \mu \mathrm{mol} \mathrm{kg} \mathrm{gr}^{-1} \mathrm{yr}^{-1}$ for surface waters of the SR03. This means that values of $\sim 0.20 \mu \mathrm{mol} \mathrm{kg}{ }^{-1} \mathrm{yr}^{-1}$ due to circulation processes can be expected in $\frac{\partial \mathrm{DIC} \mathrm{C}^{\mathrm{BIO}}}{\partial t}$ for surface waters, which is comparable to the average of our findings (Table 5), $0.32 \pm 0.24 \mu \mathrm{mol} \mathrm{kg}{ }^{-1} \mathrm{yr}^{-1}$, and could indicate that the change in $\mathrm{O}_{2}$ is related to circulation processes.

The variability of the SAMW and AAIW layers south of Tasmania has been related to variability in the northward Ekman transport that drives the northward movement of AASW (Rintoul and England, 2002; Sallée et al., 2006, 2012). A scenario of intensification of the upwelling near the Antarctic Divergence would lead to an increase in the northward Ekman transport, conditioning the properties of these water mass layers, particularly for SAMW, which is mostly formed north of the SAF. There is a significant freshening of the SAMW layer $\left(-0.0026 \pm 0.0001 \mathrm{psu} \mathrm{yr}^{-1}\right.$, not shown) between 1995 and 2011 that could be related to higher inputs of AASW into the SAMW layer and is consistent with the increase in Ekman transport. Besides, an intensification of the winds due to the positive trend of the SAM favours the ventilation and thus the increase in $\mathrm{C}_{\mathrm{ANT}}$ uptake by both water mass layers (Matear and Lenton, 2008). Our results indicate that the change in DIC in the SAMW and AAIW layers is driven mostly by the uptake of atmospheric $\mathrm{CO}_{2}\left(\frac{\partial \mathrm{DIC}}{\partial t} \approx \frac{\partial \mathrm{C}_{\mathrm{ANT}}}{\partial t}\right.$, Table 4$)$. The increase in $\mathrm{C}_{\mathrm{ANT}}$ in the SAMW layer is higher than that found for the upper ocean 
Table 7. Comparison between $\frac{\partial \mathrm{C}_{\mathrm{ANT}}}{\partial t}$ from the present study and the values of $\Delta \mathrm{C}_{\mathrm{ANT}}$ from the two-regression and eMLR methods. $\mathrm{RMSE}=$ root mean square error. ${ }^{* *}$ The value of $\frac{\partial \mathrm{C}_{\mathrm{ANT}}}{\partial t}$ in the AABW layer is considered negligible because it falls below the accuracy of the back-calculation method.

\begin{tabular}{|c|c|c|c|}
\hline \multirow[t]{2}{*}{ Layer } & $\begin{array}{l}\partial \mathrm{C}_{\mathrm{ANT}} / \partial t \\
\left(\mu \mathrm{mol} \mathrm{kg}-1 \mathrm{yr}^{-1}\right)\end{array}$ & $\begin{array}{l}\Delta \mathrm{C}_{\mathrm{ANT}} \text { (two-regression) } \\
\left(\mu \mathrm{mol} \mathrm{kg}{ }^{-1} \mathrm{yr}^{-1}\right)\end{array}$ & $\begin{array}{l}\Delta \mathrm{C}_{\mathrm{ANT}}(\mathrm{eMLR}) \\
\left(\mu \mathrm{mol} \mathrm{kg}-1 \mathrm{yr}^{-1}\right)\end{array}$ \\
\hline & 1995-2011 & 1995-2011 & $1995-2011$ \\
\hline STCW & {$[0.71 \pm 0.08-0.93 \pm 0.08]$} & $0.72 \pm 0.04, \mathrm{RMSE}=5$ & $1.21 \pm 0.09, \mathrm{RMSE}=3$ \\
\hline AASW & {$[0.35 \pm 0.14-0.85 \pm 0.21]$} & $0.61 \pm 0.04, \mathrm{RMSE}=6$ & $0.67 \pm 0.10, \mathrm{RMSE}=10$ \\
\hline $\mathrm{AASW}_{\text {upw }}$ & {$[0-0.41 \pm 0.16]$} & $0.20 \pm 0.03, \mathrm{RMSE}=3$ & $0.30 \pm 0.04, \mathrm{RMSE}=3$ \\
\hline SAMW & $0.92 \pm 0.09, \mathrm{RMSE}=10$ & $0.94 \pm 0.05, \mathrm{RMSE}=5$ & $0.96 \pm 0.09, \mathrm{RMSE}=10$ \\
\hline AAIW & $0.42 \pm 0.06, \mathrm{RMSE}=10$ & $0.28 \pm 0.02, \mathrm{RMSE}=4$ & $0.43 \pm 0.02, \mathrm{RMSE}=7$ \\
\hline UCDW & - & $0.09 \pm 0.01, \mathrm{RMSE}=2$ & $0.15 \pm 0.09, \mathrm{RMSE}=3$ \\
\hline LCDW & - & $0.08 \pm 0.01, \mathrm{RMSE}=2$ & $0.28 \pm 0.15, \mathrm{RMSE}=3$ \\
\hline AABW & $* * 0.07 \pm 0.01, \mathrm{RMSE}=2$ & $0.09 \pm 0.01, \mathrm{RMSE}=1$ & $0.18 \pm 0.08, \mathrm{RMSE}=2$ \\
\hline
\end{tabular}

layers and closer to the expected values from the increase in atmospheric $\mathrm{CO}_{2}\left(\sim 1 \mu \mathrm{mol} \mathrm{kg} \mathrm{gr}^{-1}\right)$. The smaller increase in $\mathrm{C}_{\text {ANT }}$ in the AAIW layer compared to the SAMW layer (Table 4) agrees with lower ventilation of the AAIW layer south of Tasmania (see Sect. 2) due to the fact that this layer carries recently ventilated waters mixed with older waters ventilated far out the SR03 section. The lack of measurable long-term changes in $\mathrm{DIC}^{\mathrm{BIO}}$ and $\mathrm{DIC}^{\pi}$ in both AAIW and SAMW layers indicate that circulation and biological processes do not have a large effect on $\frac{\partial \mathrm{DIC}}{\partial t}$.

Deep to bottom layers of the section show significant trends for DIC that are not explained by the increase in $\mathrm{C}_{\mathrm{ANT}}$. These trends are most likely due to the advection of old and DIC-rich waters. Concretely for deep waters (UCDW and LCDW), the trends could result from an intensification of upwelling at high latitudes being offset by enhanced transport of old and $\mathrm{CO}_{2}$-rich waters to replace the upwelled waters, since the increase in DIC follows the upwelling path of the UCDW and LCDW layers (Fig. 4). We separated the UCDW layer into two latitudinal sectors: north and south of the SAF (Fig. 4). The increase in DIC in the UCDW layer north of the SAF is $0.44 \pm 0.04 \mu \mathrm{mol} \mathrm{kg} \mathrm{gr}^{-1}$ while that south of the SAF is smaller at $0.26 \pm 0.04 \mu \mathrm{mol} \mathrm{kg} \mathrm{kg}^{-1} \mathrm{yr}^{-1}$ (not shown), consistent with a greater supply of waters from the north at depth. A decrease in $\mathrm{O}_{2}$ in the UCDW to the north of the SAF occurs mostly in the upper to middle parts of the UCDW layer (Fig. 4), and this is not observed south of the SAF. The decrease in $\mathrm{O}_{2}$ is also in agreement with the arrival of waters from Indian-Pacific origin since these waters provide the characteristic oxygen minimum zone that defines UCDW (Callahan, 1972; Talley 2013). Another feature that agrees with the hypothesis of upwelling intensification is the shoaling of the ASD following the path of upwelling of the UCDW layer. This feature was also described by Bostock et al. (2013) in an oceanic climatology of $\Omega_{\mathrm{Ar}}$ and could be due to the naturally lower buffer capacity of the UCDW layer (low value of TA / DIC $\approx 1.043$ ) with respect to upper layers
(TA / DIC $\approx 1.06$ in the AASW layer). However, the greatest shoaling of the ASD in the UCDW layers compared to the AAIW layer (Table 6) is consistent with the upwelling of UCDW, as both water masses have similar TA / DIC ratios (TA / DIC $\approx 1.043$ for the UCDW layer and TA / DIC $\approx 1.042$ for the AAIW layer). Furthermore, the increase in $\mathrm{SiO}_{4}$ found in deep-bottom layers (Table 4) could also indicate the arrival of old waters to the section that are progressively enriched in $\mathrm{SiO}_{4}$ (e.g. Callahan, 1972).

Statistically significant decreases in $\mathrm{pH}_{\mathrm{T}}$ with time were observed in all water mass layers (Table 4), with the greatest change in surface water masses coinciding with the greatest DIC changes. The decrease in $\mathrm{pH}_{\mathrm{T}}$ in the STCW and SAMW layers is related to the increase in the uptake of $\mathrm{C}_{\mathrm{ANT}}$, while

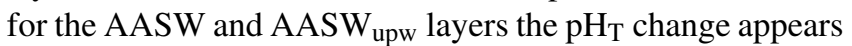
to be linked to the upwelling of DIC-rich waters at high latitudes. At deep layers, the tongue of water of $\mathrm{pH}_{\mathrm{T}}=7.9$ off the shelf is reduced in 2011 compared to 1995 (Fig. 2e, f), which is consistent with the advection of DIC-rich waters in the section due to the enhanced upwelling. The different rates of $\mathrm{pH}_{\mathrm{T}}$ change in the water masses is in part related to the buffering capacity of the waters. The AASW layer has lower temperature than the STCW layer $\left(\sim 2.3^{\circ} \mathrm{C}\right.$ for the AASW layer compared to $\sim 11.0^{\circ} \mathrm{C}$ for the STCW layer, mean values for the period 1995-2011) and lower buffer capacity than the STCW $(\mathrm{TA} / \mathrm{DIC} \approx 1.058$ for the AASW layer versus $\mathrm{TA} / \mathrm{DIC} \approx 1.095$ for STCW). For similar increases in DIC (Table 4) the decrease in $\mathrm{pH}_{\mathrm{T}}$ in the AASW is expected to be higher than in the STCW layer.

In terms of carbon, previous studies concluded that the intensification of the upwelling (as a consequence of the SAM variability) caused a reduction in the uptake of $\mathrm{CO}_{2}$ by the Southern Ocean between the 1980s and 2000s due to the outgassing of $\mathrm{CO}_{2}$ near the Antarctic Divergence (Le Quére et al., 2007; Lovenduski et al., 2008). Landschützer et al. (2015) showed that the efficiency of the Southern Ocean $\mathrm{CO}_{2}$ sink declined through the 1990s, and the trend reversed 

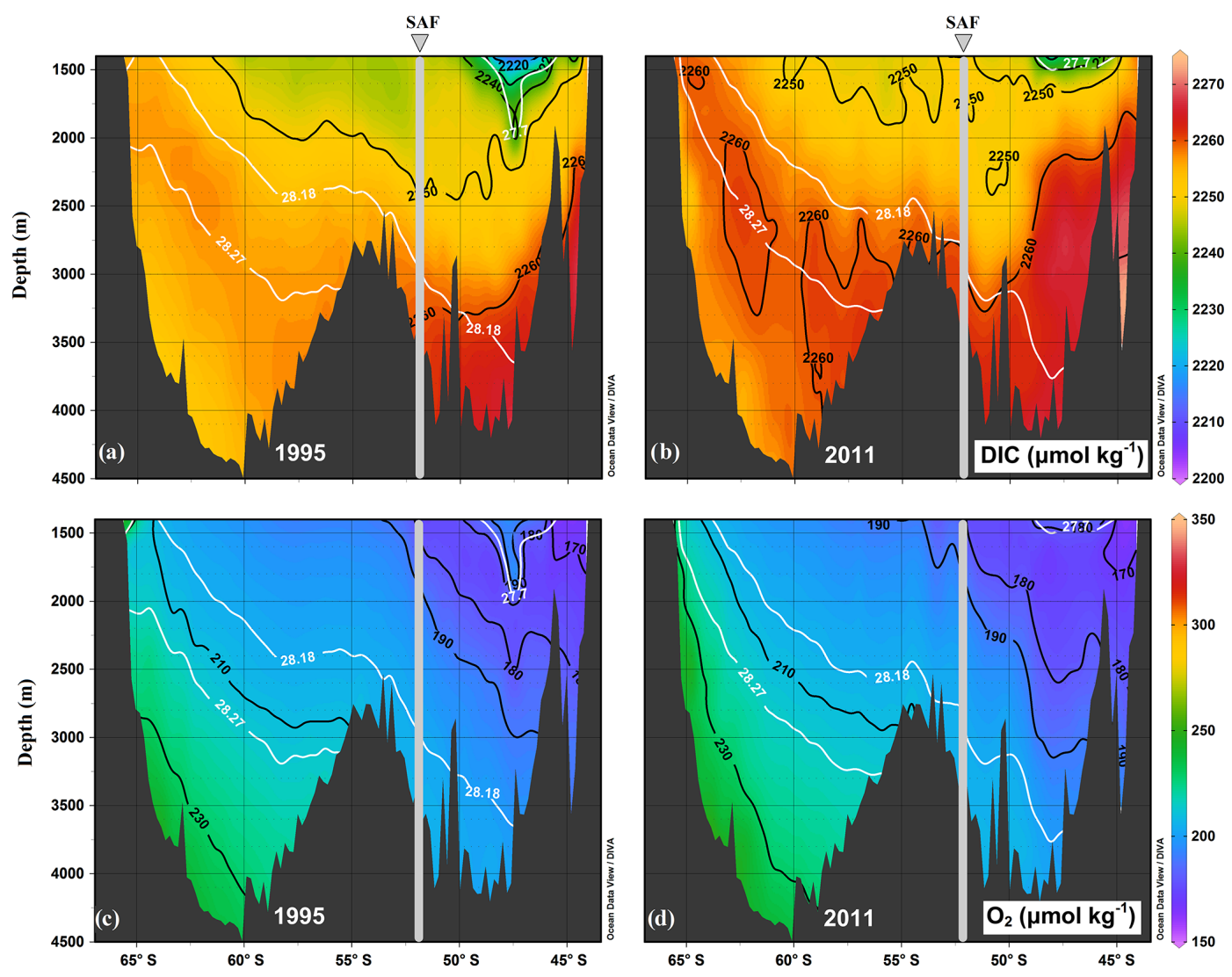

Figure 4. Distribution of (a, b) dissolved inorganic carbon (DIC) and (c, d) dissolved oxygen $\left(\mathrm{O}_{2}\right)$ in the 1995 and 2011 cruises for deepbottom layers of the section. The location of the Sub-Antarctic Front (SAF) is also shown as well as the neutral surfaces $\left(\gamma^{\mathrm{n}}\right.$, white lines) limiting the UCDW, LCDW and AABW layers.

from about 2002, although the reversal in the sink efficiency was not zonally uniform. The results from Landschützer et al. (2015) are consistent with a carbon sink influenced by the upwelling of DIC-rich waters at high latitudes, and superimposed on this is the near-surface response to atmospheric forcing that modifies the sink efficiency and could mask longer-term trends in the upwelling of DIC-rich waters at high latitudes. A comparison of our results with those of Landschützer et al. (2015) is problematic as their data are restricted to surface waters and our analysis is on long-term trends in water mass properties below $50 \mathrm{~m}$ depth. Both data sets do show continued uptake of $\mathrm{CO}_{2}$ throughout the period of study and indicate the importance of the circulation in influencing the regional carbon sink, which has also been established by recent model results (DeVries et al., 2007).

Our results also agree with the conclusions from different model simulations done by Matear and Lenton (2008), who established that intense wind regimes (associated with a positive phase in the SAM) favour the uptake of $\mathrm{C}_{\mathrm{ANT}}$ and ventilation of the SAMW and AAIW layers. These authors highlighted the complex response of the uptake of $\mathrm{CO}_{2}$ by the Southern Ocean due to the diverse forcing acting on upper layers, which can be also seen in our results (e.g. differences in the biogeochemical changes in the AASW and AASW $\mathrm{upw}_{\text {w }}$ layers). Matear and Lenton (2008) also noticed the complex relationship between the upwelling and subduction areas of the Southern Ocean, with the same drivers acting in opposite directions for the changes in non-anthropogenic DIC with respect to the changes in $\mathrm{C}_{\mathrm{ANT}}$ uptake.

\section{Sensitivity of the results to underlying assumptions}

This section considers the sensitivity of assumptions used to calculate temporal changes in $\mathrm{C}_{\mathrm{ANT}}$, including errors associated with the assumption of steady state in the oceanic circulation and remineralisation processes, and the sensitivity to stoichiometric ratios for the biological processes.

\subsection{Comparison of $\mathrm{C}_{\mathrm{ANT}}$ changes using other methods}

We compared the changes in $\mathrm{C}_{\mathrm{ANT}}$ obtained in our study with the results from two regression-based methodologies (Table 7): the extended multiple linear regression (eMLR) method (Friis et al., 2005) and the two-regression method (Thacker, 2012). These methods use repeated hydrodynamic sections to quantify the temporal change in $\mathrm{C}_{\mathrm{ANT}}$. 
The eMLR method (Friis et al., 2005) estimates the change in $\mathrm{C}_{\mathrm{ANT}}$ between two repeats of a hydrodynamic section by establishing MLRs for each section and relating the observed DIC for each observation to a set of other measured oceanic variables:

$\operatorname{DIC}_{(t)}=a_{0(t)}+a_{1(t)} P_{1(t)}+\ldots+a_{n(t)} P_{n(t)}$,

where $a_{x(t)}$ are the coefficients of the fit between DIC and the $n$ observed variables $\left(P_{1}, \ldots P_{n}\right)$ chosen for the fit, all measured at the time $(t)$ of the survey.

Taking the difference between DIC at two times, $t 1$ and $t 2$, gives an equation for the change in $\mathrm{C}_{\mathrm{ANT}}$ over the time period between the two hydrographic surveys $\left(\Delta \mathrm{C}_{\mathrm{ANT}}\right)$ :

$$
\begin{aligned}
\Delta \mathrm{C}_{\mathrm{ANT}} & =a_{0(t 2)}-a_{0(t 1)}+\left(a_{1(t 2)}-a_{0(t 1)}\right) P_{1(t 2)}+\ldots \\
& +\left(a_{n(t 2)}-a_{0(t 1)}\right) P_{n(t 2)}
\end{aligned}
$$

The two-regression method was introduced by Thacker (2012) as an improvement in regression-based methods. The region of study is first divided into sub-regions since the empirical relationships between DIC and other environmental variables vary spatially (Thacker, 2012). MLRs are investigated between DIC and other measured variables (predictors) using a stepwise technique. The procedure is applied for each sub-region using all data from the repeated surveys within the period to be investigated, resulting in an optimal MLR for each sub-region (similar to Eq. 6). A linear regression with time is established for the residuals (observed DIC - predicted DIC) of the regional fits, which directly gives $\Delta \mathrm{C}_{\mathrm{ANT}}$ averaged over the space-time in each sub-region. The purpose of the first MLR is to remove the natural variability of DIC, leaving the anthropogenic signal and noise (random variability) in the residuals, and the second MLR is used to separate the anthropogenic signal from the noise.

We applied both methodologies within the different water mass layers, which were separated by $\gamma^{\mathrm{n}}$ and used as subregions. The predictor variables of $\theta, \mathrm{S}, \sigma_{0}$, nitrate $\left(\mathrm{NO}_{3}\right)$, $\mathrm{SiO}_{4}$ and AOU were used for the MLR procedures. The three methodologies estimate similar rates of increase in $\mathrm{C}_{\mathrm{ANT}}$ for most water mass layers (Table 7). In the STCW layer, the value of $\Delta \mathrm{C}_{\mathrm{ANT}}$ (eMLR) is higher than our maximum estimate of $\frac{\partial \mathrm{C}_{\mathrm{ANT}}}{\partial t}$ and the value obtained from the two-regression method. The eMLR method is less suitable for the upper layers of the ocean subject to high seasonal to inter-annual variability, such as the STCW layer, resulting in large residuals that bias the regression (Friis et al., 2005). For the AAIW layer, the increase in $\mathrm{C}_{\mathrm{ANT}}$ estimated by the two-regression method is half the increase that is established by our method and the eMLR method. The lower value of the trend estimated by the two-regression method is due to the fact that the two-regression method uses stepwise MLR. This means that the two-regression method only considers those predictors that give the best fit while the eMLR method is forced to consider all the predictors in the fit. This is also the cause of the low RMSE obtained with the two-regression method compared to both our trends and those obtained by the eMLR method. For deep to bottom layers, the two-regression method estimates a small increase in $\mathrm{C}_{\mathrm{ANT}}$ similar to the one found in this study for the AABW layer (Table 7) that can be considered negligible given the resolution of the back-calculation method $\left( \pm 6 \mu \mathrm{mol} \mathrm{kg}{ }^{-1}\right)$. The eMLR method finds increases in $\mathrm{C}_{\mathrm{ANT}}$ (with relatively high uncertainties) higher than the two-regression method that over the 16-year period also give values of $\mathrm{C}_{\mathrm{ANT}}$ change lower than the resolution of our back-calculation method (although close to it for the LCDW layer, $\sim 5 \mu \mathrm{mol} \mathrm{kg}^{-1}$ for the 16-year period).

\subsection{Circulation and biological processes at steady state}

The back-calculation method assumes the circulation of the ocean and the biological processes are at steady state. The contribution of non-linear mixing is unknown, and some of the changes in DIC in the water mass layers could be erroneously included in the estimates of $\mathrm{C}_{\mathrm{ANT}}$ rather than as a non-anthropogenic change in DIC. The non-steady state of the circulation in our analysis is included to some extent through the changes in CDIS $^{\pi}$ (Eqs. 3, 4), which is solved by the OMP analysis, which is subjected to the limitations of quantifying the mixing mostly through thermohaline changes in the water masses (Sect. S2).

For biological processes, remineralisation rates are usually considered to be at steady state (Sarmiento et al., 1992). Climate change has been suggested as potentially driving changes in carbon fixation and export that can influence the uptake of $\mathrm{CO}_{2}$ by the oceans (Falkowski et al., 1998). Pahlow and Riebesell (2000) first suggested that decadal changes in remineralisation rates occurred in the deep waters of the Northern Hemisphere, although this is still a matter of debate (e.g. Li and Peng, 2002; Najjar, 2009).

Metzl et al. (1999) and Shadwick et al. (2015) observed that the uptake of $\mathrm{CO}_{2}$ over the sub-Antarctic zone (SAZ, between the SAF and the STF) in summer is mostly controlled by biological processes. If a change in remineralisation rates has occurred, i.e. the changes in $\mathrm{DIC}^{\mathrm{BIO}}$ are due to biological effects, a change in nutrient concentrations of the water masses would be expected. The detection of long-term trends of nutrients in upper layers of the ocean can be masked by short-timescale physical processes such as changes in the mixed layer depth, mesoscale activity and advection (Sambrotto and Mace, 2000; Rintoul and Trull, 2001; Sallée et al., 2010). We did not find a measurable trend in nutrient concentrations for any of the layers in the period 1995-2011, except for an increase in $\mathrm{SiO}_{4}$ over the Antarctic Divergence (Table 4) that is most likely due to the upwelling of $\mathrm{SiO}_{4}$ rich deep waters. We cannot confidently assign the changes in DIC ${ }^{\mathrm{BIO}}$ and its impact on $\frac{\partial \mathrm{C}_{\mathrm{ANT}}}{\partial t}$ in upper layers (Table 5) to any particular process, and instead we provide a range of values for $\frac{\partial \mathrm{C}_{\mathrm{ANT}}}{\partial t}$ (Table 4$)$. For the scenario of intensification 
of the Antarctic upwelling, the increase in low- $\mathrm{O}_{2}$ and DICrich waters would increase the content of DIC in subsurface

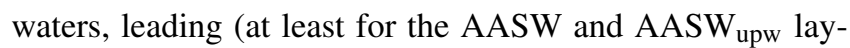
ers) to values of $\frac{\partial \mathrm{C}_{\mathrm{ANT}}}{\partial t}$ closer to the lower limit of the range (i.e. $\frac{\partial \mathrm{DIC}}{\partial t} \gg \frac{\partial \mathrm{C}_{\mathrm{ANT}}}{\partial t}$, Table 4).

In deep layers of the section, the increase in DIC is not explained by the long-term change in any of the terms in Eq. (1), which is another implication of considering the circulation at steady state. The differences found in the increase in DIC in the UCDW layer north and south of the SAF (Sect. 4.3, Fig. 4) add consistency to the idea of the advection of older waters to the section. Considering these differences, we can assign a change in DIC of at least $\sim 0.20 \pm 0.02 \mu \mathrm{mol} \mathrm{kg} \mathrm{yr}^{-1}$ (lower rate of increase in DIC found in deep-bottom layers, Table 4) due to the upwelling intensification. Since the AASW and AASW $\mathrm{upw}_{\text {layers are }}$ the most affected by the upwelling, we can correct the values of $\frac{\partial C_{\text {ANT }}}{\partial t}$ in these layers for this effect (trends with ${ }^{* *}$ in Table 4).

\subsection{Changes in the rates of export of particulate organic carbon and silicate from surface layers}

We assume that the export of particulate organic carbon (POC), from upper ocean layers (STCW, AASW and $\mathrm{AASW}_{\text {upw }}$ ) and remineralisation in the water column, was constant between 1995 and 2011. The high latitudes are considered important in terms of POC export, mostly because these areas are dominated by large phytoplankton, in particular diatoms (Buesseler, 1998; Sambrotto and Mace, 2000), and rapid export of carbon to deep waters from phytoplankton blooms is possible (DiTullio et al., 2000; Lourey and Trull, 2001). The POC exported is remineralised to DIC below the mixed layer (Wassman et al., 1990; Asper and Smith Jr., 1999; Trull et al., 2001a; Fripiat et al., 2015).

Our results show that the increase in DIC in mode and intermediate waters is fully explained by the uptake of atmospheric $\mathrm{CO}_{2}$, which could indicate that there was no detectable change in the rate of export of POC over the 1995-2011 period. Estimates of POC export in the SAZ $(\sim 3800 \mathrm{~m})$, the SAF $(\sim 3100 \mathrm{~m})$ and the PFZ $(\sim 1500 \mathrm{~m})$ using moored sediment traps near the section (Trull et al., 2001b) were $0.5,0.8$ and $1.0 \mathrm{~g} \mathrm{C} \mathrm{m}^{-2} \mathrm{yr}^{-1}$, respectively. If all this POC is fully remineralised in the UCDW layer (with a mean thickness of $2000 \mathrm{~m}$ ), we obtain a range of 0.02 $0.04 \mu \mathrm{mol} \mathrm{kg}^{-1} \mathrm{yr}^{-1}$ for the maximum increase in DIC due to the export of POC. This increase is close to the uncertainty of the total DIC increase estimated for the UCDW layer, which means that in order to generate an increase in DIC similar to that found in the UCDW layer, the rate of POC export should be $\sim 10$ times higher than the observed rates. This change should certainly be noticeable in $\frac{\partial \mathrm{DIC} \mathrm{BIO}}{\partial t}$ in surface waters but most probably in deep waters as well, which we do not see.
The observed increase in $\mathrm{SiO}_{4}$ in deep and bottom layers of the ocean is consistent with the transport of $\mathrm{SiO}_{4}$-rich older waters to the section. For UCDW, the increase in $\mathrm{SiO}_{4}$ north of the $\mathrm{SAF}$ is higher than at south-

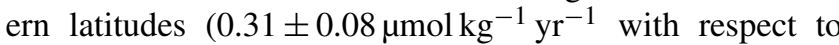
$0.19 \pm 0.04 \mu \mathrm{mol} \mathrm{kg}^{-1} \mathrm{yr}^{-1}$, not shown). Nelson et al. (1995) observed a lower dissolution rate of diatom-dominated $\mathrm{SiO}_{4}$ exported in high-latitude regions compared to lower latitudes. Nelson et al. (1995) estimated a mean silica production rate of $0.7-1.2 \mathrm{~mol} \mathrm{Si} \mathrm{m}^{-2} \mathrm{yr}^{-1}$ for regions over diatomaceous sediments and concluded that $15-25 \%$ of the silica produced in the upper ocean accumulates in the seabed. Of the silica produced in the mixed layer of the upper ocean layers, at least $50 \%$ is believed to dissolve in the upper $100 \mathrm{~m}$ of the water column (e.g. Nelson et al., 1991; DeMaster et al., 1992). For deep waters, the production rates of Nelson et al. (1995) could result in a mean increase in $\mathrm{SiO}_{4}$ of 0.08 $0.14 \mu \mathrm{mol} \mathrm{kg}{ }^{-1} \mathrm{yr}^{-1}$ in the water column $(\sim 3400 \mathrm{~m}$, mean depth). The maximum value of this increase could explain the trends of $\mathrm{SiO}_{4}$ found for the AABW layer (Table 4), but $32-48 \%$ of the increase in $\mathrm{SiO}_{4}$ in deep bottom layers is not explained by the remineralisation of exported silica and is most likely the result of the advection of older $\mathrm{SiO}_{4}$-rich waters to the section.

\subsection{Stoichiometric ratios for biological processes}

The back-calculation method and the OMP analysis assume constant stoichiometric ratios for remineralisation. The theoretical Redfield ratios (Redfield, 1934, 1958) are usually considered as a mean for the whole ocean, although they can vary from the theoretical value due to changes in phytoplankton species composition, the food-web structure and nutrient availability (Martiny et al., 2013).

We carried out a sensitivity analysis on the Redfield ratios following Álvarez et al. (2014), to obtain values of stoichiometric ratios for the section. A battery of OMP analyses were done with varying values of $R_{\mathrm{N}}$ between 9 and 10 in increments of $0.2, R_{\mathrm{P}}$ between 120 and 145 in increments of 5, and $R_{\mathrm{Si}}$ between 0 and 8 in increments of 2. For each variation in the stoichiometric ratios, an OMP analysis was made for each section in order to determine best-fit $R$ values and whether there were differences in time for the stoichiometric ratios along the sections. The smallest residuals (differences between the nutrients measured and those estimated by the OMP analysis) were obtained for $R_{\mathrm{N}}=9$ and $R_{\mathrm{P}}=125$. The residuals of $\mathrm{SiO}_{4}$ did not change significantly for any value of $R_{\mathrm{Si}}$ and we consider $\mathrm{SiO}_{4}$ to be a conservative variable. These results indicate $\frac{R_{\mathrm{P}}}{R_{\mathrm{N}}}=13.8$, in agreement with values obtained for the region $\left(\frac{R_{\mathrm{P}}}{R_{\mathrm{N}}} \in[8-15]\right.$, Lourey and Trull, 2001). 


\section{Conclusions}

The results of our analysis south of Tasmania over the 19952011 period support a scenario of intensification of upwelling in the vicinity of the Antarctic Divergence due to an increase in the westerly winds at high latitudes, most probably linked to the variability of the SAM. The intensification of the upwelling favours the advection of older waters to deep-bottom layers of the section where we found a net increase in DIC over the 16-year period. The enhanced upwelling causes the eventual entrainment of low- $\mathrm{O}_{2}$ and DIC-rich waters into upper layers, explaining the trends of decreasing $\mathrm{O}_{2}$ and increasing non-anthropogenic DIC found in surface waters close to the Antarctic Divergence. This scenario also implies the intensification of the convergence north of the SAF, implying a more efficient ventilation of the SAMW and AAIW layers and thus an efficient uptake of atmospheric $\mathrm{CO}_{2}$ by these layers. The enhanced upwelling lowers the uptake of $\mathrm{C}_{\mathrm{ANT}}$ in the AASW layer, but the effect of ventilation more than compensates that of the upwelling, allowing the increase in $\mathrm{C}_{\mathrm{ANT}}$ in this layer. The atmospheric warming reduces the dissolution of $\mathrm{CO}_{2}$ in upper layers north of the PF, presenting increases in DIC lower than expected from the atmospheric $\mathrm{CO}_{2}$ increase.

Our results rely on a limited number of sections that are studied every 3-7 years and can only provide a long-term (decadal) average view of changes in water masses. More surface observations and repeated deep-ocean sections are needed to help resolve inter-annual changes in the Southern Ocean carbon sink and to determine the main drivers and feedback to the carbon-climate system. The effort to maintain hydrographic sections with $\mathrm{CO}_{2}$ system measurements would also benefit from additional direct measurements of more variables of the carbon system, e.g. $\mathrm{pH}$, which has not been measured in the SR03 section.

Data availability. The section data are available through the Global Ocean Data Analysis Project (https://www.nodc.noaa.gov/ocads/ oceans/GLODAPv2/; Key et al., 2015; Olsen et al., 2016). The original data for the different cruises were corrected following the QC recommendations in GLODAPv2.

The Supplement related to this article is available online at https://doi.org/10.5194/bg-14-5217-2017-supplement.

Competing interests. The authors declare that they have no conflict of interest.

Special issue statement. This article is part of the special issue "The Ocean in a High- $\mathrm{CO}_{2}$ World IV". It is a result of the 4th Inter- national Symposium on the Ocean in a High- $\mathrm{CO}_{2}$ World, Hobart, Australia, 3-6 May 2016.

Acknowledgements. The SR03 section was sampled as part of the World Ocean Circulation Experiment $\mathrm{CO}_{2}$ Survey (WOCE, http://woceatlas.ucsd.edu), and more recently the Global Ocean Ship-Based Hydrographic Investigation Program (GO-SHIPS, http://www.go-ship.org). Carbon system parameters contribute to the International Ocean Carbon Coordination Project of the United Nations Intergovernmental Oceanographic Commission (IOCCP, http://www.ioccp.org). Support for measurements on the section were provided to Steve Rich Rintoul and Bronte Tilbrook by the Antarctic Climate and Ecosystems Cooperative Research Centre (ACE CRC) and the Australian Climate Change Science Program. Logistic support for the section and ship time on the RSV Aurora Australis was provided by the Australian Antarctic Division. The many scientific staff involved in the hydrographic sections and the officers and crew of the ship were critical to obtaining good quality data. We especially want to thank the work by Kate Berry and Mark Pretty for high quality DIC and TA data, and for the hydrochemistry teams and CTD watches of multiple cruises and especially Mark Rosenberg and Rebecca Cowley. Paula Conde Pardo is a postdoctoral fellow supported by the ACE-CRC Project R2.1: Carbon Uptake and Chemical Change.

Edited by: Kristy Kroeker

Reviewed by: Marta Álvarez and one anonymous referee

\section{References}

Álvarez, M., Brea, S., Mercier, H., and Álvarez-Salgado, X. A.: Mineralization of biogenic materials in the water masses of the South Atlantic Ocean. I: assessment and results of an optimum multiparameter analysis, Prog. Oceanogr., 123, 1-23, https://doi.org/10.1016/j.pocean.2013.12.007, 2014.

Amante, C. and Eakins, B. W.: ETOPO1 1 Arc-Minute Global Relief Model: Procedures, Data Sources and Analysis, NOAA Technical Memorandum NESDIS NGDC-24, National Geophysical Data Center, NOAA, https://doi.org/10.7289/V5C8276M, 2009.

Anderson, L. A. and Sarmiento, J. L.: Redfield ratios of remineralization determined by nutrient data analysis, Global Biogeochem. Cy., 8, 65-80, https://doi.org/10.1029/93GB03318, 1994.

Aoki, S., Bindoff, N. L., and Church, J. A.: Interdecadal water mass changes in the Southern Ocean between $30^{\circ} \mathrm{E}$ and $160^{\circ} \mathrm{E}, 32$, L07607, https://doi.org/10.1029/2004GL022220, 2005.

Aoki, S., Mizuta, G., Sasaki, H., Sasai, Y., Rintoul, S. R., and Bindoff, N. L.: Atlantic-Pacific asymmetry of subsurface temperature change and frontal response of the Antarctic Circumpolar Current for the recent three decades, J. Oceanogr., 71, 623-636, https://doi.org/10.1007/s10872-015-0284-6, 2015.

Armour, K. and Bitz, C. M.: Observed and projected trends in Antarctic sea ice, US Clivar Variations Newsletter, 13, 12-19, 2015. 
Asper, V. L. and Smith Jr., W. O.: Particle fluxes during austral spring and summer in the southern Ross Sea, Antarctica, J. Geophys. Res., 104, 5345-5359, 1999.

Baines, P. G., Edwards, R. J., and Fandry, C. B.: Observations of a new baroclinic current along the western continental slope of Bass Strait, Aust. J. Mar. Fresh. Res., 34, 155-157, 1983.

Bates, N. R., Astor, Y. M., Church, M. J., Currie, K., Dore, J. E., González-Dávila, M., Lorenzoni, L., Muller-Karger, F., Olafsson, J., and Santana-Casiano, J. M.: A time-series view of changing ocean chemistry due to ocean uptake of anthropogenic $\mathrm{CO}_{2}$ and ocean acidification, Oceanography 27, 126141, https://doi.org/10.5670/oceanog.2014.16, 2014.

Belkin, I. M. and Gordon, A. L.: Southern Ocean fronts from the Greenwich meridian to Tasmania, J. Geophys. Res., 101, 36753696, 1996.

Bender, M., Ellis, T., Tans, P., Francey, R., and Lowe, D.: Variability in the $\mathrm{O}_{2} / \mathrm{N}_{2}$ ratio of southern hemisphere air, 1991-1994: Implications for the carbon cycle, Global Biogeochem. Cy., 10, 9-21, 1996.

Bindoff, N. L. and Church, J. A.: Warming of the Water Column in the Southwest Pacific Ocean, Nature, 357, 59-62, 1992.

Bindoff, N. L. and McDougall, T. J.: Diagnosing Climate Change and Ocean Ventilation using Hydrographic Data, J. Phys. Oceanogr., 24, 1137-1152, 1994.

Boland, F. M. and Church, J. A.: The East Australian Current 1978, Deep-Sea Res., 28, 937-957, https://doi.org/10.1016/01980149(81)90011-X, 1981.

Bostock, H. C., Mikaloff Fletcher, S. E., and Williams, M. J. M.: Estimating carbonate parameters from hydrographic data for the intermediate and deep waters of the Southern Hemisphere oceans, Biogeosciences, 10, 6199-6213, https://doi.org/10.5194/bg-106199-2013, 2013.

Broecker, W. S.: "NO" a conservative water mass tracer, Earth Planet. Sc. Lett., 23, 8761-8776, 1974.

Buesseler, K. O.: The decoupling of production and particle export in the surface ocean, Global Biogeochem. Cy., 12, 297-310, 1998.

Callahan, J. E.: The structure and circulation of Deep Water in the Antarctic, Deep-Sea Res., 19, 563-575, 1972.

Carter, B. R., Feely, R. A., Mecking, S., Cross, J. N., Macdonald, A. M., Siedlecki, S. A., Talley, L. D., Sabine, C. L., Millero, F. J., Swift, J. H., Dickson, A. G., and Rodgers, K. B.: Two decades of Pacific anthropogenic carbon storage and ocean acidification along Global Ocean Ship-based Hydrographic Investigations Program sections P16 and P02, Global Biogeochem. Cy., 31, 306-327, https://doi.org/10.1002/2016GB005485, 2017.

Chen, C.-T. A. and Millero, F. J.: Gradual increase of oceanic $\mathrm{CO}_{2}$, Nature, 277, 205-206, 1979.

Chen, C.-T. A., Pytkowicz, M. R., and Olson, E. J.: Evaluation of the calcium problem in the South Pacific, Geochem. J., 16, 1-10, 1982.

Davis, R.: Intermediate-depth circulation of the Indian and South Pacific oceans measured by autonomous floats, J. Phys. Oceanogr., 35, 683-707, 2005.

Deacon, G. E. R.: The hydrology of the Southern Ocean, Cambridge University Press, 15, 1-124, 1937.

DeMaster, D. J., Dunbar, R. B., Gordon, L. I., Leventer, A. R., Morrison, J. M., Nelson, D. M., Nittrouer, C. A., and Smith Jr., W. O.: The cycling and accumulation of organic matter and biogenic sil- ica in high-latitude environments: The Ross Sea, Oceanography, 5, 146-153, 1992.

DeVries, T., Holzer, M., and Primeau, F.: Recent increase in oceanic carbon uptake driven by weaker upper-ocean overturning, Nature, 542, 215-218, https://doi.org/10.1038/nature21068, 2017.

Dickson, A. G.: Thermodynamics of the dissociation of boric acid in synthetic seawater from 273.15 to 318.15 K, Deep-Sea Res. Pt. I, 37, 755-766, https://doi.org/10.1016/0198-0149(90)90004-F, 1990.

Dickson, A. G. and Millero, F. J.: A comparison of the equilibrium constants for the dissociation of carbonic acid in seawater media, Deep-Sea Res. Pt. I, 34, 1733-1743, https://doi.org/10.1016/0198-0149(87)90021-5, 1987.

Dickson, A. G., Sabine, C. L., and Christian, J. R.: Guide to Best Practices for Ocean $\mathrm{CO}_{2}$ Measurements, PICES Special Publication 3, 191 pp., 2007.

Dickson, R. R. and Brown, J.: The production of North Atlantic Deep Water: sources, rates, and pathways, J. Geophys. Res., 99, 12319-12341, https://doi.org/10.1029/94JC00530, 1984.

DiTullio, G. R., Grebmeier, J. M., Arrigo, K. R., Lizotte, M. P., Robinson, D. H., Leventer, A., Barry, J. P., VanWoert, M. L., and Dunbar, R. B.: Rapid and early export of Phaeocystis antarctica blooms in the Ross Sea, Antarctica, Nature, 404, 595-598, 2000.

Dlugokencky, E. J., Lang, P. M., Mund, J. W., Crotwell, A. M., Crotwell, M. J., and Thoning, K. W.: Atmospheric Carbon Dioxide Dry Air Mole Fractions from the NOAA ESRL Carbon Cycle Cooperative Global Air Sampling Network, 1968-2015, Version: 2016-08-30, ftp://aftp.cmdl.noaa.gov/data/trace_gases/co2/flask/ surface/ (last access: 14 November 2017), 2016.

Doney, S. C., Victoria, J. F., Feely, R. A., and Kleypas, J. A.: Ocean Acidification: The other $\mathrm{CO}_{2}$ problem, Annu. Rev. Mar. Sci., 1, 169-92, https://doi.org/10.1146/annurev.marine.010908.163834, 2009.

Falkowski, P. G., Barber, R. T., and Smetacek, V.: Biogeochemical Controls and Feedbacks on Ocean Primary Production, Science, 281, 200-206, https://doi.org/10.1126/science.281.5374.200, 1998.

Fay, A. R., McKinley, G. A., and Lovenduski, N. S.: Southern Ocean carbon trends: Sensitivity to methods, Geophys. Res. Lett., 41, 6833-6840, https://doi.org/10.1002/2014GL061324, 2014.

Feely, R. A., Sabine, C. L., Lee, K., Berelson, W., Kleypas, J., Fabry, V. J., and Millero, F. J.: The impact of anthropogenic $\mathrm{CO}_{2}$ on the $\mathrm{CaCO}_{3}$ system in the oceans, Sience, 305, 362-366, 2004.

Foster, T. D. and Carmack, E. C.: Frontal zone mixing and Antarctic Bottom Water formation in the southern Weddell Sea, Deep-Sea Res., 23, 301-307, 1976.

Friis, K., Körtzinger, A., J. Pätsch, J., and Wallace, D. W. R.: On the temporal increase of anthropogenic $\mathrm{CO}_{2}$ in the subpolar North Atlantic, Deep-Sea Res. Pt. I, 52, 681-698, https://doi.org/10.1016/j.dsr.2004.11.017, 2005.

Fripiat, F., Elskens, M., Trull, T. W., Blain, S., Cavagna, A.J., Fernandez, C., Fonseca-Batista, D., Planchon, F., Raimbault, P., Roukaerts, A., and Dehairs, F.: Significant mixed layer nitrification in a natural iron-fertilized bloom of the Southern Ocean, Global Biogeochem. Cy., 29, 1929-1943, https://doi.org/10.1002/2014GB005051, 2015.

Fukamachi, Y., Rintoul, S. R., Church, J. A., Aoki, S., Sokolov, S., Rosenberg, M. A., and Wakatsuchi, M.: Strong export of Antarc- 
tic Bottom Water east of the Kerguelen plateau, Nature, 3, 327$331,2010$.

Gordon, A. L. and Tchernia, P.: Waters of the continental margin off Adélie Coast, Antarctica, in: Antarctic Oceanology II: The Australian-New Zealand Sector, edited by: Hayes, D. E., Antarctic Research Series 19, American Geophysical Union, Washington, DC, 59-69, 1972.

Gruber, N.: Anthropogenic $\mathrm{CO}_{2}$ in the Atlantic Ocean, Global Biogeochem. Cy., 12, 165-191, 1998.

Gruber, N., Gloor, M., Mikaloff Fletcher, S. E., Doney, S. C., Dutkiewicz, S., Follows, M. J., Gerber, M., Jacobson, A. R., Joos, F., Lindsay, K., Menemenlis, D., Mouchet, A., Müller, S. A., Sarmiento, J. L., and Takahashi, T.: Oceanic sources, sinks, and transport of atmospheric $\mathrm{CO}_{2}$, Global Biogeochem. Cy., 23, GB1005, https://doi.org/10.1029/2008GB003349, 2009.

Hanawa, K. and Talley, L. D.: Mode waters, in: Ocean Circulation and Climate, edited by: Siedler, G., Church, J., and Gould, J., International Geophysics Series, Academic Press, New York, 373386, 2001.

Hauri, C., Doney, S. C., Takahashi, T., Erickson, M., Jiang, G., and Ducklow, H. W.: Two decades of inorganic carbon dynamics along the West Antarctic Peninsula, Biogeosciences, 12, 67616779, https://doi.org/10.5194/bg-12-6761-2015, 2015.

Helm, K. P., Bindoff, N. L., and Church, J. A.: Observed decreases in oxygen content of the global ocean, Geophys. Res. Lett., 38, L23602, https://doi.org/10.1029/2011GL049513, 2011.

Herraiz-Borreguero, L. and Rintoul, S. R.: Regional circulation and its impact on upper ocean variability south of Tasmania, Deep-Sea Res. Pt. II, 58, 2071-2081, https://doi.org/10.1016/j.dsr2.2011.05.022, 2011.

Hill, K. L., Rintoul, S. R., Ridgway, K. R., and Oke, P. R.: Decadal changes in the South Pacific western boundary current system revealed in observations and ocean state estimates, J. Geophys. Res., 116, C01009, https://doi.org/10.1029/2009JC005926, 2011.

Hood, E. M., Sabine, C. L., and Sloyan, B. M.: The GO-SHIP Repeat Hydrography Manual: a Collection of Expert Reports and Guidelines, IOCCP Report Number 14, OCPO Publication Series Number 134, http://www.go-ship.org/HydroMan.html (last access: 14 November 2017), 2010.

Ikegami, H. and Kanamori, S.: Calcium-Alkalinity-Nitrate Relationship in the North Pacific and the Japan Sea, Journal of the Oceanographical Society of Japan, 39, 9-14, 1983.

Iudicone, D., Speich, S., Madec, G., and Blanke, B.: The Global Conveyor Belt from a Southern Ocean perspective, J. Phys. Oceanogr., 38, 1401-1425, https://doi.org/10.1175/2007JPO3525.1, 2008.

Jackett, D. R. and McDougall, T. J.: A Neutral Density Variable for the World's Oceans, J. Phys. Oceanogr., 27, 237-263, 1997.

Jacobs, S.: Observations of change in the Southern Ocean, Philos. T. R. Soc. A, 364, 1657-1681, https://doi.org/10.1098/rsta.2006.1794, 2006.

Jacobs, S. S.: On the nature and significance of the Antarctic Slope Front, Mar. Chem., 35, 9-24, 1991.

Johnson, G. C.: Quantifying Antarctic Bottom Water and North Atlantic Deep Water volumes, J. Geophys. Res., 113, C05027, https://doi.org/10.1029/2007JC004477, 2008.
Joyce, T. and Corry, C.: Requirements for WOCE Hydrographic Programme Data Reporting, WHPO Publication 90-1 Revision 2, WOCE Report 67/91, Woods Hole, Mass., USA, 1994.

Key, R. M., Olsen, A., van Heuven, S., Lauvset, S. K., Velo, A., Lin, X., Schirnick, C., Kozyr, A., Tanhua, T., Hoppema, M., Jutterström, S., Steinfeldt, R., Jeansson, E., Ishi, M., Perez, F. F., and Suzuki, T.: Global Ocean Data Analysis Project, Version 2 (GLODAPv2), ORNL/CDIAC-162, ND-P093, Carbon Dioxide Information Analysis Center, Oak Ridge National Laboratory, US Department of Energy, Oak Ridge, Tennessee, https://doi.org/10.3334/CDIAC/OTG.NDP093_GLODAPv2, 2015.

Khatiwala, S., Primeau, F., and Hall, T.: Reconstruction of the history of anthropogenic $\mathrm{CO}_{2}$ concentrations in the ocean, Nature, 462, 346-350, https://doi.org/10.1038/nature08526, 2009.

Kouketsu, S. and Murata, A. M.: Detecting decadal scale increases in anthropogenic $\mathrm{CO}_{2}$ in the ocean, Geophys. Res. Lett., 41, 4594-4600, https://doi.org/10.1002/2014GL060516, 2014.

Lacarra, M., Houssais, M.-N., Sultan, E., Rintoul, S. R., and Herbaut, C.: Summer hydrography on the shelf off Terre Adélie/George V Land based on the ALBION and CEAMARC observations during the IPY, Polar Sci., 5, 88-103, https://doi.org/10.1016/j.polar.2011.04.008, 2011.

Landschützer, P., Gruber, N., Haumann, A., Rödenbeck, C., Bakker, D. C. E., van Heuven, S., Hoppema, M., Metzl, N., Sweeney, C., Takahashi, T., Tilbrook, B., and Wanninkhof, R.: The reinvigoration of the SouthernOcean carbon sink, Science, 349, 12211224, https://doi.org/10.1126/science.aab2620, 2015.

Lauvset, S. K., Gruber, N., Landschützer, P., Olsen, A., and Tjiputra, J.: Trends and drivers in global surface ocean $\mathrm{pH}$ over the past 3 decades, Biogeosciences, 12, 1285-1298, https://doi.org/10.5194/bg-12-1285-2015, 2015.

Lenton, A. and Matear, R. J.: Role of the Southern Annular Mode (SAM) in Southern Ocean $\mathrm{CO}_{2}$ uptake, Global Biogeochem. Cy., 21, GB2016, https://doi.org/10.1029/2006GB002714, 2007.

Lenton, A., Metzl, N., Takahashi, T., Kuchinke, M., Matear, R. J., Roy, T., Sutherland, S. C., Sweeney, C., and Tilbrook, B.: Global Biogeochem. Cy., 26, GB2021, https://doi.org/10.1029/2011GB004095, 2012.

Lenton, A., Tilbrook, B., Law, R. M., Bakker, D., Doney, S. C., Gruber, N., Ishii, M., Hoppema, M., Lovenduski, N. S., Matear, R. J., McNeil, B. I., Metzl, N., Mikaloff Fletcher, S. E., Monteiro, P. M. S., Rödenbeck, C., Sweeney, C., and Takahashi, T.: Seaair $\mathrm{CO}_{2}$ fluxes in the Southern Ocean for the period 1990-2009, Biogeosciences, 10, 4037-4054, https://doi.org/10.5194/bg-104037-2013, 2013.

Le Quéré, C., Rödenbeck, C., Buitenhuis, E. T., Conway, T. J., Langenfelds, R., Gomez, A., Labuschagne, C., Ramonet, M., Nakazawa, T., Metz, N., Gillett, N., and Heimann, M.: Saturation of the Southern Ocean $\mathrm{CO}_{2}$ Sink Due to Recent Climate Change, Science, 316, 1735-1738, https://doi.org/10.1126/science.1136188, 2007.

Lewis, E. and Wallace, D. W. R.: Program Developed for $\mathrm{CO}_{2}$ System Calculations. ORNL/CDIAC-105. Carbon Dioxide Information Analysis Center, Oak Ridge National Laboratory, U.S. Department of Energy, Oak Ridge, Tennessee, 1998.

Li, Y.-H. and Peng, T.-H.: Latitudinal change of remineralization ratios in the oceans and its implication 
for nutrient cycles, Global Biogeochem. Cy., 16, 1130, https://doi.org/10.1029/2001GB001828, 2002.

Lourey, K. J. and Trull, T. W.: Seasonal nutrient depletion and carbon export in the Subantarctic and Polar Frontal Zones of the Southern Ocean south of Australia, J. Geophys. Res., 106, 31463-31487, 2001.

Lovenduski, N. S., Gruber, N., and Doney, S. C.: Towards a mechanistic understanding of the decadal trends in the Southern Ocean carbon sink, Global Biogeochem. Cy., 22, GB3016, https://doi.org/10.1029/2007GB003139, 2008.

Lumpkin, R. and Speer, K.: Global Ocean Meridional Overturning, J. Phys. Oceanogr., 37, 2550-2562, https://doi.org/10.1175/JPO3130.1, 2007.

Mantyla, A. W. and Reid, J. L.: On the origins of deep and bottom waters of the Indian Ocean, J. Geophys. Res., 100, 2417-2439, 1995.

Marshall, G. J.: Analysis of recent circulation and thermal advection change in the northern Antarctic Peninsula, Int. J. Climatol., 22, 1557-1567, https://doi.org/10.1002/joc.814, 2002.

Marshall, G. J.: Trends in the Southern Annular Mode from observations and reanalyses, J. Climate, 16, 4134-4143, 2003.

Marsland, S. J., Bindoff, N. L., Williams, G. D., and Budd, W. F.: Modeling water mass formation in the Mertz Glacier Polynya and Adélie Depression, East Antarctica, J. Geophys. Res., 109, C11003, https://doi.org/10.1029/2004JC002441, 2004.

Martiny, A. C., Pham, C. T. A., Primeau, F. W., Vrugt, J. A., Moore, J. K., Levin, S. A., and Lomas, M. W.: Strong latitudinal patterns in the elemental ratios of marine plankton and organic matter, Nature, 6, 279-283, https://doi.org/10.1038/NGEO1757, 2013.

Matear, R. and Lenton, A.: Impact of historical climate change on the Southern Ocean carbon cycle, J. Climate, 21, 5820-5834, https://doi.org/10.1175/2008JCLI2194.1, 2008.

Matear, R. J., Hirst, A. C., and McNeil, B. I.: Changes in dissolved oxygen in the Southern Ocean with climate change, Geochem. Geophy. Geosy., 1, 1525-2027, 2000.

McCartney, M. S.: The subtropical recirculation of mode waters, J. Mar. Res., 40 (Suppl.), 427-464, 1977.

McDougall, T. J.: Neutral surfaces in the ocean: implications for modelling, Geophys. Res. Lett., 14, 97-800, 1987.

McNeil, B. I., Tilbrook, B., and Matear, R. J.: Accumulation and uptake of anthropogenic $\mathrm{CO}_{2}$ in the Southern Ocean, south of Australia between 1968 and 1996, J. Geophys. Res., 106, 3143131445, 2001.

Mehrbach, C., Culberson, C. H., Hawley, J. E., and Pytkowicz, R. M.: Measurement of the apparent dissociation constants of carbonic acid in seawater at atmospheric pressure, Limnol. Oceanogr., 18, 897-907, https://doi.org/10.4319/lo.1973.18.6.0897, 1973.

Metzl, N., Tilbrook, B., and Poisson, A.: The annual $\mathrm{fCO}_{2}$ cycle and the air-sea $\mathrm{CO}_{2}$ flux in the sub-Antarctic Ocean, Tellus, 51, 849-861, 1999.

Moore, J. K. and Abbott, M. R.: Phytoplankton chlorophyll distributions and primary production in the Southern Ocean, J. Geophys. Res., 105, 28709-28722, 2000.

Moore, J. K., Abbott, M. R., and Richman, J. R.: Location and dynamics of the Antarctic Polar Front from satellite sea surface temperature data, J. Geophys. Res., 104, 3059-3073, 1999.
Mosby, H.: The waters of the Atlantic Antarctic Ocean, Scientific Results of the Norwegian Antarctic Expeditions 1927-1928, 1, 11, 131 pp., 1934.

Murata, A., Kumamoto, Y., Watanabe, S., and Fukasawa, M.: Decadal increases of anthropogenic $\mathrm{CO}_{2}$ in the South Pacific subtropical ocean along $32^{\circ} \mathrm{S}$, J. Geophys. Res., 112, C05033, https://doi.org/10.1029/2005JC003405, 2007.

Najjar, R.: The dark side of marine carbon, Nat. Geosci., 2, 603 604, https://doi.org/10.1038/NGEO812, 2009.

Nelson, D. M., Ahern, J. A., and Herlihy, L. J.: Cycling of biogenic silica within the upper water column of the Ross Sea, Mar. Chem, 35, 461-476, 1991.

Nelson, D. M., Tréguer, P., Brzezinsk, M. A., Leynaert, A., and Quéguiner, B.: Production and dissolution of biogenic silica in the ocean: Revised global estimates, comparison with regional data and relationship to biogenic sedimentation, Global Biogeochem. Cy., 9, 359-372, 1995.

Olsen, A., Key, R. M., van Heuven, S., Lauvset, S. K., Velo, A., Lin, X., Schirnick, C., Kozyr, A., Tanhua, T., Hoppema, M., Jutterström, S., Steinfeldt, R., Jeansson, E., Ishii, M., Pérez, F. F., and Suzuki, T.: The Global Ocean Data Analysis Project version 2 (GLODAPv2) - an internally consistent data product for the world ocean, Earth Syst. Sci. Data, 8, 297-323, https://doi.org/10.5194/essd-8-297-2016, 2016.

Orr, J. C., Fabry, V. J., Aumont, O., Bopp, L., Doney, S. C., Feely, R. A., Gnanadesikan, A., Gruber, N., Ishida, A., Joos, F., Key, R. M., Lindsay, K., Maier-Reimer, E., Matear, R., Monfray, P., Mouchet, A., Najjar, R. J., Plattner, G.-K., Rodgers, K. B., Sabine, C. L., Sarmiento, J. L., Schlitzer, R., Slater, R. D., Totterdell, I. J., Weirig, M.-F., Yamanaka, Y., and Yool, A.: Anthropogenic ocean acidification over the twenty-first century and its impact on calcifying organisms, Nature, 437, 681-686, https://doi.org/10.1038/nature04095, 2005.

Orsi, A. H., Whitworth III, T., and Nowlin, W. D.: On the meridional extent and fronts of the Antarctic Circumpolar Current, Deep-Sea Res. Pt. I, 42, 641-673, 1995.

Pahlow, M. and Riebesell, U.: Temporal trends in deep ocean Redfield ratios, Science, 287, 831-833, 2000.

Pardo, P. C., Vázquez-Rodríguez, M., Pérez, F. F., and Ríos, A. F.: $\mathrm{CO}_{2}$ air-sea disequilibrium and preformed alkalinity in the Pacific and Indian Oceans calculated from subsurface layer data, J. Marine Syst., 84, 67-77, https://doi.org/10.1016/j.jmarsys.2010.08.006, 2011.

Pardo, P. C., Pérez, F. F., Khatiwala, S., and Ríos, A. F.: Anthropogenic $\mathrm{CO}_{2}$ estimates in the Southern Ocean: Storage partitioning in the different water masses, Prog. Oceanogr., 120, 230-242, https://doi.org/10.1016/j.pocean.2013.09.005, 2014.

Peña-Molino, B., Rintoul, S. R., and Mazloff, M. R.: Barotropic and baroclinic contributions to along-stream and across-stream transport in the Antarctic Circumpolar Current, J. Geophys. Res.-Oceans, 119, 8011-8028, https://doi.org/10.1002/2014JC010020, 2014.

Purkey, S. G. and Johnson, G. C.: Global Contraction of Antarctic Bottom Water between the 1980s and 2000s, J. Climate, 25, 5830-5844, https://doi.org/10.1175/JCLI-D-11-00612.1, 2012.

Redfield, A.: On the proportions of organic derivatives in sea water and their relation to the composition of plankton, in: James Johnstone Memorial Volume, edited by: Daniel, R. J., University Press of Liverpool, 177-192, 1934. 
Redfield, A.: The biological control of chemical factors in the environment, Am. Sci., 46, 205-221, 1958.

Ridgway, K. R.: Seasonal circulation around Tasmania: An interface between eastern and western boundary dynamics, J. Geophys. Res., 112, C10016, https://doi.org/10.1029/2006JC003898, 2007.

Rintoul, S. R.: On the origin and influence of Adelie Land Bottom Water, in: Ocean, Ice, and Atmosphere: Interactions at the Antarctic continental margin, edited by: Jacobs. S. and Weiss, R., Antarct. Res. Ser., 75, 151-171, 1998.

Rintoul, S. R. and Bullister, J. L.: A late winter hydrographic section from Tasmania to Antarctica, Deep-Sea Res. Pt. I, 46, 14171454, 1999.

Rintoul, S. R. and England, M. H.: Ekman Transport Dominates Local Air-Sea Fluxes in Driving Variability of Subantarctic Mode Water, J. Phys. Oceanogr., 32, 1308-1321, 2002.

Rintoul, S. R. and Sokolov, S.: Baroclinic transport variability of the Antarctic Circumpolar Current south of Australia (WOCE repeat section SR3), J. Gephys. Res., 106, 2815-2832, 2001.

Rintoul, S. R. and Trull, T. W.: Seasonal evolution of the mixed layer in the Subantarctic Zone south of Australia, J. Geophys. Res., 106, 31447-31462, 2001.

Rintoul, S. R., Donguy, J. R., and Roemmich, D. H.: Seasonal evolution of upper ocean thermal structure between Tasmania and Antarctica, Deep-Sea Res. Pt. I, 44, 1185-1202, 1997.

Sabine, C. L., Feely, R. A., Gruber, N., Key, R. M., Lee, K., Bullister, J. L., Wanninkhof, R., Wong, C. S., Wallace, D. W. R., Tilbrook, B., Millero, F. J., Peng, T.-H., Kozyr, A., Ono, T., and Rios, A. F.: The Oceanic Sink for Anthropogenic $\mathrm{CO}_{2}$, Science, 305, 367-371, 2004.

Sabine, C. L., Feely, R. A., Millero, F. J., Dickson, A. G., Langdon, C., Mecking, S., and Greeley, D.: Decadal changes in Pacific carbon, J. Geophys. Res., 113, C07021, https://doi.org/10.1029/2007JC004577, 2008.

Sallée, J.-B., Wienders, N., Speer, K., and Morow, R.: Formation of subantarctic mode water in the southeastern Indian Ocean, Ocean Dynam., 56, 525-542, https://doi.org/10.1007/s10236005-0054-x, 2006.

Sallée, J. B., Speer, K., and Morrow, R.: Response of the Antarctic Circumpolar Current to Atmospheric Variability, J. Climate, 21, 3020-3039, https://doi.org/10.1175/2007JCLI1702.1, 2008.

Sallée, L. B., Speer, K. G., and Rintoul, S. R.: Zonally asymmetric response of the Southern Ocean mixed-layer depth to the Southern Annular Mode, Nat. Geosci., 3, 273-279, 2010.

Sallée, J. B., Matear, R. J., Rintoul, S. R., and Lenton, A.: Localized subduction of anthropogenic carbon dioxide in the Southern Hemisphere oceans, Nature, 5, 579-584, https://doi.org/10.1038/NGEO1523, 2012.

Sambrotto, R. N. and Mace, B. J.: Coupling of biological and physical regimes across the Antarctic Polar Front as reflected by nitrogen production and recycling, Deep-Sea Res. Pt. II, 47, 33393367, 2000.

Sarmiento, J. L. and Sundquist, E. T.: Revised budget for the oceanic uptake of anthropogenic carbon dioxide, Nature, 356, 589-593, 1992.

Sarmiento, J. L., Hughes, T. M. C., Stouffer, R. J., and Manabe, S.: Simulated response of the ocean carbon cycle to anthropogenic climate warming, Nature, 393, 245-249, 1998.
Sarmiento, J. L., Gruber, N., Brzezinski, M. A., and Dunne, J. P.: High-latitude controls of thermocline nutrients and low latitude biological productivity, Nature, 427, 56-60, 2004.

Shadwick, E. H., Trull, T. W., Tilbrook, B., Sutton, A. J., Schulz, E., and Sabine, C. L.: Seasonality of biological and physical controls on surface ocean $\mathrm{CO}_{2}$ from hourly observations at the Southern Ocean Time Series site south of Australia, Global Biogeochem. Cy., 29 223-238, https://doi.org/10.1002/2014GB004906, 2015.

Sloyan, B. M. and Rintoul, S. R.: The Southern Ocean Limb of the Global Deep Overturning Circulation, J. Phys. Oceanogr., 31, 143-173, 2001.

Sloyan, B. M., Ridgway, K., and Cowley, R.: The East Australian Current and Property Transport at $27^{\circ} \mathrm{S}$ from 2012 to 2013, J. Phys. Oceanogr., 46, 993-1008, https://doi.org/10.1175/JPO-D15-0052.1, 2016.

Sokolov, S. and Rintoul, S. R.: Structure of Southern Ocean fronts at $140^{\circ}$ E, J. Marine Syst., 37, 151-184, 2002.

Sokolov, S. and Rintoul, S. R.: Multiple jets of the Antarctic Circumpolar Current South of Australia, J. Phys. Oceanog. 37, 1394-1412, https://doi.org/10.1175/JPO3111.1, 2007.

Sokolov, S. and Rintoul, S. R.: Circumpolar structure and distribution of the Antarctic Circumpolar Current fronts: 1. Mean circumpolar paths, J. Geophys. Res., 114, C11018, https://doi.org/10.1029/2008JC005108, 2009.

Speer, K., Rintoul, S. R., and Sloyan, B.: The Diabatic Deacon Cell, J. Phys. Oceanogr., 30, 3212-3222, 2000.

Speich, S., Blanke, B., de Vries, P., Drijfhout, S., Döös, K., Ganachaud, A., and Marsh, R.: Tasman leakage: A new route in the global ocean conveyor belt, Geophys. Res. Lett., 29, 1416, https://doi.org/10.1029/2001GL014586, 2002.

Talley, L. D.: Closure of the global overturning circulation through the Indian Pacific, and Southern Oceans: Schematics and transports, Oceanography, 26, 80-97, https://doi.org/10.5670/oceanog.2013.07, 2013.

Thacker, W. C.: Regression-based estimates of the rate of accumulation of anthropogenic $\mathrm{CO}_{2}$ in the ocean: A fresh look, Mar. Chem., 132-133, 44-55, https://doi.org/10.1016/j.marchem.2012.02.004, 2012.

Thompson, D. W. J. and Solomon, S.: Interpretation of Recent Southern Hemisphere Climate Change, Science, 296, 895-899, https://doi.org/10.1126/science.1069270, 2002.

Tomczak, M.: A multi-parameter extension of temperature/salinity diagram techniques for the analysis of non-isopycnal mixing, Prog. Oceanogr., 10, 147-171, 1981.

Tréguer, P. J.: The Southern Ocean silica cycle, Comptes Rendus Geoscience, 346, 279-286, https://doi.org/10.1016/j.crte.2014.07.003, 2014.

Trull, T., Rintoul, S. R., Hadfield, M., and Abraham, E. R.: Circulation and seasonal evolution of polar waters south of Australia: Implications for iron fertilization of the Southern Ocean, DeepSea Res. Pt. II, 48, 2439-2466, 2001a.

Trull, T. W., Bray, S. G., Manganini, S. J., Honjo, S., and Frangois, R.: Moored sediment trap measurements of carbon export in the Subantarctic and Polar Frontal Zones of the Southern Ocean, south of Australia, J. Geophys. Res., 106, 31489-31509, 2001 b.

Uppstrom, L. R.: The boron/chloronity ratio of deep-sea water from the Pacific Ocean, Deep-Sea Res., 21, 161-162, 1974.

van Heuven, S., Pierrot, D., Rae, J. W. B., Lewis, E., and Wallace, D. W. R.: MATLAB Program Developed for $\mathrm{CO}_{2}$ 
System Calculations, ORNL/CDIAC-105b, Carbon Dioxide Information Analysis Center, Oak Ridge National Laboratory, U.S. Department of Energy, Oak Ridge, Tennessee, https://doi.org/10.3334/CDIAC/otg.CO2SYS_MATLAB_v1.1, 2011.

van Heuven, S., Hoppema, M., Jones, E. M., and de Baar, H. J. W.: Rapid invasion of anthropogenic $\mathrm{CO}_{2}$ into the deep circulation of theWeddell Gyre, Philos. T. R. Soc. A, 372, 20130056, https://doi.org/10.1098/rsta.2013.0056, 2014.

van Wijk, E. M. and Rintoul, S. R.: Freshening drives contraction of Antarctic Bottom Water in the Australian Antarctic Basin, Geophys. Res. Lett., 41, 1657-1664, https://doi.org/10.1002/2013GL058921, 2014.

Vázquez-Rodríguez, M., Padín, X. A., Pardo, P. C., Ríos, A. F., and Pérez, F. F.: The subsurface layer reference to calculate preformed alkalinity and air-sea $\mathrm{CO}_{2}$ disequilibrium in the Atlantic Ocean, J. Marine Syst., 94, 52-63, https://doi.org/10.1016/j.jmarsys.2011.10.008, 2012.

Verdy, A., Dutkiewicz, S., Follows, M. J., Marshall, J., and Czaja, A.: Carbon dioxide and oxygen fluxes in the Southern Ocean: Mechanisms of Interannual variability, Global Biogeochem. Cy., 21, GB2020, https://doi.org/10.1029/2006GB002916, 2007.

Wassmann, P., Vernet, M., Mitchell, B. G., and Rey, F.: Mass sedimentation of Phaeocystis pouchetii in the Barents Sea, Mar. Ecol.-Prog. Ser., 66, 183-195, 1990.
Waters, J. F., Millero, F. J., and Sabine, C. L.: Changes in South Pacific anthropogenic carbon, Global Biogeochem. Cy., 25, GB4011, https://doi.org/10.1029/2010GB003988, 2011.

Weiss, R.: Carbon dioxide in water and seawater: the solubility of a non-ideal gas, Mar. Chem., 2, 203-215, https://doi.org/10.1016/0304-4203(74)90015-2, 1974.

Whitworth III, T. and Nowlin Jr., W. D.: Water masses and currents of the Southern Ocean at the Greenwich meridian, J. Geophys. Res., 92, 6462-6476, 1987.

Williams, N. L., Feely, R. A., Sabine, C. L., Dickson, A. G., Swift, J. H., Talley, L. D., and Russell, J. L.: Quantifying anthropogenic carbon inventory changes in the Pacific sector of the Southern Ocean, Mar. Chem., 174, 147-160, https://doi.org/10.1016/j.marchem.2015.06.015, 2015.

Wong, A. P. S., Bindoff, N. L., and Church, J. A.: Large-scale freshening of intermediate waters in the Pacific and Indian oceans, Nature, 400, 440-443, 1999.

Zickfeld, K., Fyfe, J. C., Eby, M., and Weaver, A. J.: Comment on "Saturation of the Southern Ocean $\mathrm{CO}_{2}$ Sink Due to Recent Climate Change", Science 319, 570, https://doi.org/10.1126/science.1146886, 2008. 